\title{
Enhancing data informed strategic governance in education in Estonia
}

The Estonian education system is considered as one of the best performing systems among OECD countries, combining quality and equity in education. A testament to Estonia's commitment to education excellence and continuous improvement, the design of the Estonian Education Strategy 2035 goes beyond strict education performance and encompasses the knowledge, skills and attitudes for people to thrive in the 21 st century.

Estonia is currently undergoing a full re-organisation of its school network to align with the reform of its local administration and to improve the quality and efficiency of education. One of the main features of the Estonian education system is a high degree of autonomy of the education institutions and decentralised governance. However, the Estonian authorities and school owners recognise the need to achieve a better balance between accountability and autonomy, which requires providing the right information for all levels of the education system.

The Estonian Ministry of Education and Research (MoER) therefore initiated a review of its education monitoring system, including the selection of indicators underpinning the Estonian Education Strategy 2035. The overall goal is to strengthen data-informed decision making in education through improvements to the education monitoring system, as the use of data and indicators has been deemed an essential component for the realisation of the Estonian Education Strategy 2035.

As part of this process, a project to support the design and implementation of the education monitoring system in Estonia was developed under a Grant Agreement between the European Commission's Directorate General for Structural Reform Support (DG REFORM) and the OECD. This Policy Perspective presents the final output of this collaboration between the MoER, the European Commission, and the OECD.

The OECD reviewed existing data and monitoring processes in Estonia, prepared guidelines for education monitoring and proposed a coherent set of indicators to strengthen monitoring practices, promote school improvement, inform national and local decision making, and, ultimately, support the achievement of the goals set in the Estonian Education Strategy 2035. As Estonia moves forward, it will be important to keep on paying attention to the various necessary elements for sustaining data-informed decision making, such as data quality, data relevance, and stakeholders' capacity. This Policy Perspective will be valuable not only for Estonia, but also to the many countries that are looking to strengthen monitoring practices, select relevant indicators, and promote data-informed decision making at every governance level to steer school improvement.

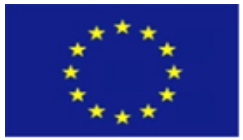

Funded by the European Union and implemented in co-operation with the European Commission's DG REFORM
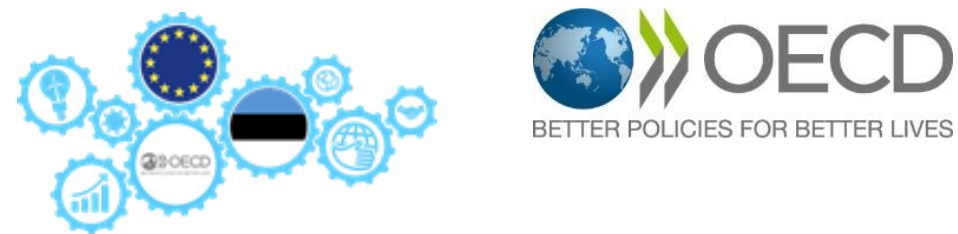


\section{Table of contents}

\section{Enhancing data informed strategic governance in education in Estonia}

An overview of the project and methodology

Education monitoring in Estonia: an overview 6

Guidelines for effective education monitoring in Estonia 12

A coherent set of indicators for education monitoring in Estonia 17

References $\quad 35$

Annex A. Summary of project outputs $\quad 37$

Annex B. Composition of the Advisory Group 38

Annex C. OECD team members 39

\section{FIGURES}

$\begin{array}{ll}\text { Figure 1. Timeline of the project } & 5\end{array}$

$\begin{array}{ll}\text { Figure 2. Methodology of the project } & 5\end{array}$

Figure 3. School autonomy, Teaching and Learning International Study (TALIS) 2018

Figure 4. Smart and Active Estonia $2035 \quad 8$

Figure 5. Framework for system evaluation/monitoring 9

Figure 6. Framework for effective education policy implementation 13

Figure 7. Strategic interactions of the goals and action trajectories of the Estonian Education Strategy 15

\section{TABLES}

Table 1. Summary of country comparison of education system evaluation and monitoring 10

Table 2. Indicators mapped to Action Trajectory 1.1 23

Table 3. Indicators mapped to Action Trajectory $1.2 \quad 24$

Table 4. Indicators mapped to Action Trajectory 1.3 25

Table 5. Indicators mapped to Action Trajectory $2.1 \quad 26$

Table 6. Indicators mapped to Action Trajectory $2.2 \quad 27$

Table 7. Indicators mapped to Action Trajectory $2.3 \quad 28$

Table 8. Indicators mapped to Action Trajectory $2.4 \quad 29$

Table 9. Indicators mapped to Action Trajectory 2.5 30

Table 10. Indicators mapped to Action Trajectory 3.1 31

Table 11. Indicators mapped to Action Trajectory 3.2

Table 12. Summary of indicators proposed at national, local and at school level 34

Table 13. OECD outputs delivered for the project $\quad 37$

Table 14. Teams from the MoER, the European Commission, and the OECD working on the project 38 


\section{Introduction}

Estonia is considered as one of the strong performing education systems among OECD countries, combining quality and equity in education according to 15 year-old student performance in the international student assessment the OECD Programme for International Student Assessment (PISA) (OECD, 2019[1]). However, national and PISA data show that there remain significant disparities between schools, and especially between regions (OECD, 2020[2] ). Evidence furthermore suggests there is a need to improve permeability across the education system, and to create learning environments that cross the borders between formal and non-formal learning, and between different levels and types of education, and address the risk of early school leaving (OECD, 2020[2]).

One of the main features of the Estonian education system is a high degree of autonomy of the education institutions and decentralised governance. In Estonia, governance of the education system is shared between central and local authorities, and schools have a high level of autonomy for resource allocation. The state sets national standards and establishes principles of education funding, supervision and quality assessment (OECD, 2020[2]). Local government reform and school network reform were intended to increase administrative capacity of local authorities and improve the quality and efficiency of education provision (Santiago et al., 2016[3] . These objectives, however, have not been fully realised yet.

Acknowledging the role of monitoring and evaluation in education system improvement and decision making, the Estonian education authorities aim to enhance their monitoring system across education levels and through the various levels of education governance. The use of relevant evidence and data is at the core of strategic education governance, and thus essential to the improvement of learners' experience and of the quality of education as a whole (OECD, 2013 $[4]$ ). The Estonian authorities and school owners therefore recognise the need to achieve a better balance between accountability and autonomy, and have identified four barriers to reach this balance in the current education monitoring system:

- The fragmentation and lack of coherence of the current sub-systems of monitoring (e.g. between self-evaluation, school improvement planning, external evaluation), which hinders policy coherence and does not support efforts towards school improvement and learners' progress.

- The lack of agreement on what are meaningful indicators to monitor key education information, including the quality of teaching and learning, the risk of low achievement, and the progress of educational institutions regarding strategic objectives.

- Limited knowledge and skills of several key stakeholders in data analysis and use, including of parents and learners themselves.

- The need for advice on addressing issues of data management and use, including matters of privacy, ethics and risks mitigation.

Against this backdrop, Estonia is developing its new Education Strategy 2035 that aims to guide the education system in the mid-term. In particular, the Education Strategy 2035 is geared towards the accomplishment of the three following strategic goals:

- Learning opportunities are diverse and accessible, and the education system enables smooth transitions between different levels and types of education.

- The approach to learning and teaching is learner-focused, forward-looking and helps learners to succeed in life.

- Learning options are responsive to labour market needs (Estonian Ministry of Education and Research, 2019[5]).

However, the Estonian education authorities consider that enhancing and updating the current monitoring system is critical to provide the right information for all levels of the education system, and ultimately achieve the goals set in the Education Strategy 2035. As an encompassing roadmap for Estonia's 


\section{4 | No. 47 - Enhancing data informed strategic governance in education in Estonia}

education system, the Education Strategy 2035 can serve as a stepping-stone to develop a coherent monitoring system that encompasses relevant education indicators.

To facilitate the development of such monitoring system in Estonia, a project called "Enhancing data-informed strategic governance in education in Estonia" was developed under a Grant Agreement between the European Commission's Directorate General for Structural Reform Support (DG REFORM) and the OECD. This document, prepared by the OECD in consultation with the Estonian Ministry of Education and Research (MoER) and the European Commission, is the final of a series of outputs produced as part of this project. It is based on information provided by the Estonian MoER about the draft Education Strategy 2035, on the analysis and outputs developed throughout the project, including primary information and feedback collected from stakeholders (Annex A) and on weekly exchanges following updates in the Strategy.

This Policy Perspective presents a proposal for a coherent set of indicators and guidelines for education monitoring in Estonia aligned to its new Education Strategy 2035. It aims to inform Estonia as it prepares to implement its Strategy and to set up the monitoring system and indicators to gauge its progress. Following a description of the methodology for the project, the first section introduces Estonia's Education Strategy 2035, its national monitoring system in comparison with other countries and with a specific focus on schools' and local actors' perspectives on education monitoring. The second section offers guidelines for effective education monitoring in relation to the Education Strategy 2035. The third section presents the set of indicators proposed in relation to the Education Strategy 2035 (summarised at the end of the section), and a methodological reminder on the process followed to assess, select and design the indicators. A complementary Excel file (Indicator selection), including the detailed analysis for each of the proposed indicators, was provided in complement to this Policy Perspective.

\section{An overview of the project and methodology}

The project called "Enhancing data-informed strategic governance in education in Estonia" has been a collaborative action between the MoER, the European Commission and the OECD. It aimed to provide strategic advice as Estonia selects indicators and align its monitoring system to implement its Education Strategy 2035. The project was based on comparative research and analysis of policies, including past Education Strategies and associated indicators, and informed by feedback gathered from diverse stakeholders through an online survey and various consultation events.

The project lasted 18 months. During that period, the MoER, the European Commission, and the OECD, collaborated to deliver several activities to reach this final output. Figure 1 details the overall timeline of the project and Annex A documents the outputs that composed the project. During the first stage of the project, the analysis focused on the monitoring system and the data needs in Estonia, while during the second stage, the selection of indicators required to support the implementation of the Education Strategy 2035 and Estonia's education monitoring system (EMS) were the core of the analysis.

The MoER, the European Commission, and the OECD constituted an Advisory Group (Annex B) that met periodically to oversee the project and review progress. For the OECD to provide strategic advice on the alignment of the Estonian monitoring system and the selection of indicators to implement the Education Strategy 2035, a specific project team was constituted. Table 14 lists the members of the OECD team, combining expertise in indicators (Indicators of Education Systems, INES team) and in implementation (Implementing Education Policies, IEP team).

Figure 2 provides an overview of the methodology undertaken to develop this project. It presents how the different outputs relate to each other, and how the collaboration between the MoER, the European Commission, and the OECD led to the delivery of the final set of indicators and guidelines presented in this Policy Perspective. 
No. 47 - Enhancing data informed strategic governance in education in Estonia | $\mathbf{5}$

Figure 1. Timeline of the project

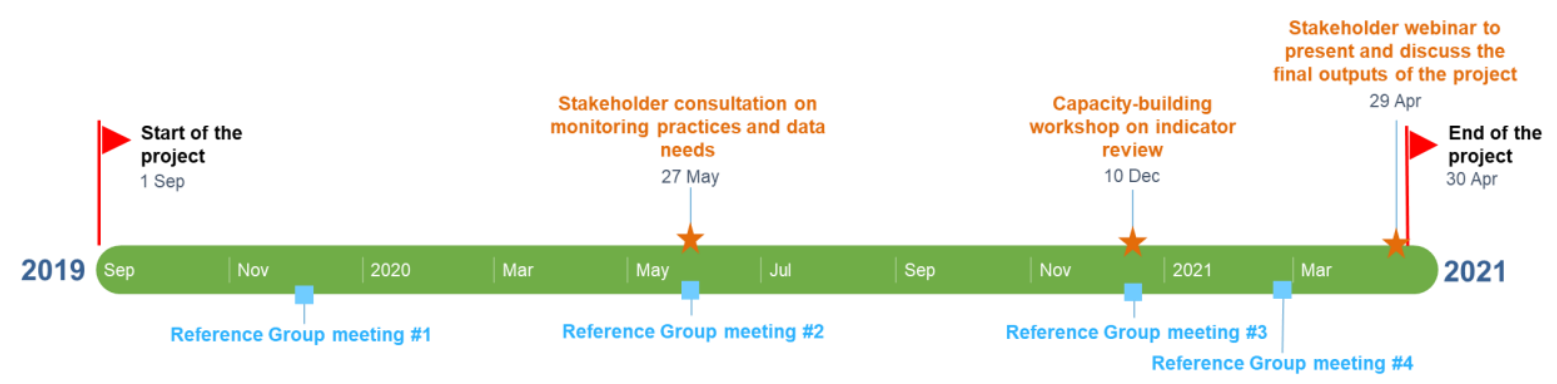

Comparative desk study of Estonia's current education monitoring system

Development of a framework to map education monitoring practices

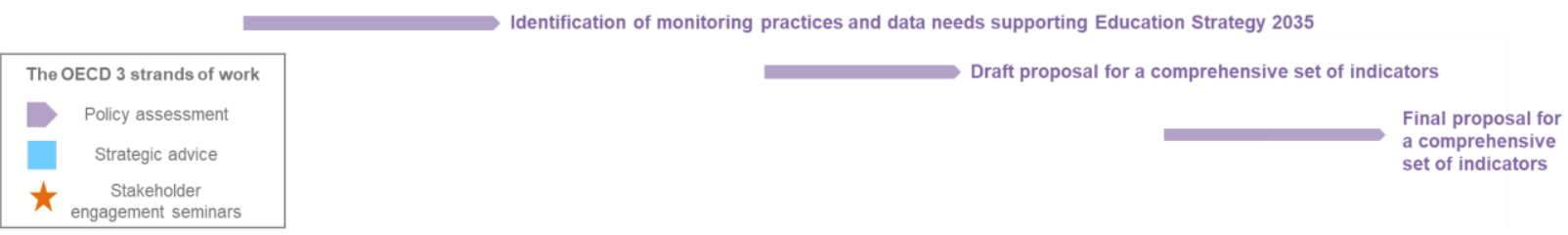

Figure 2. Methodology of the project

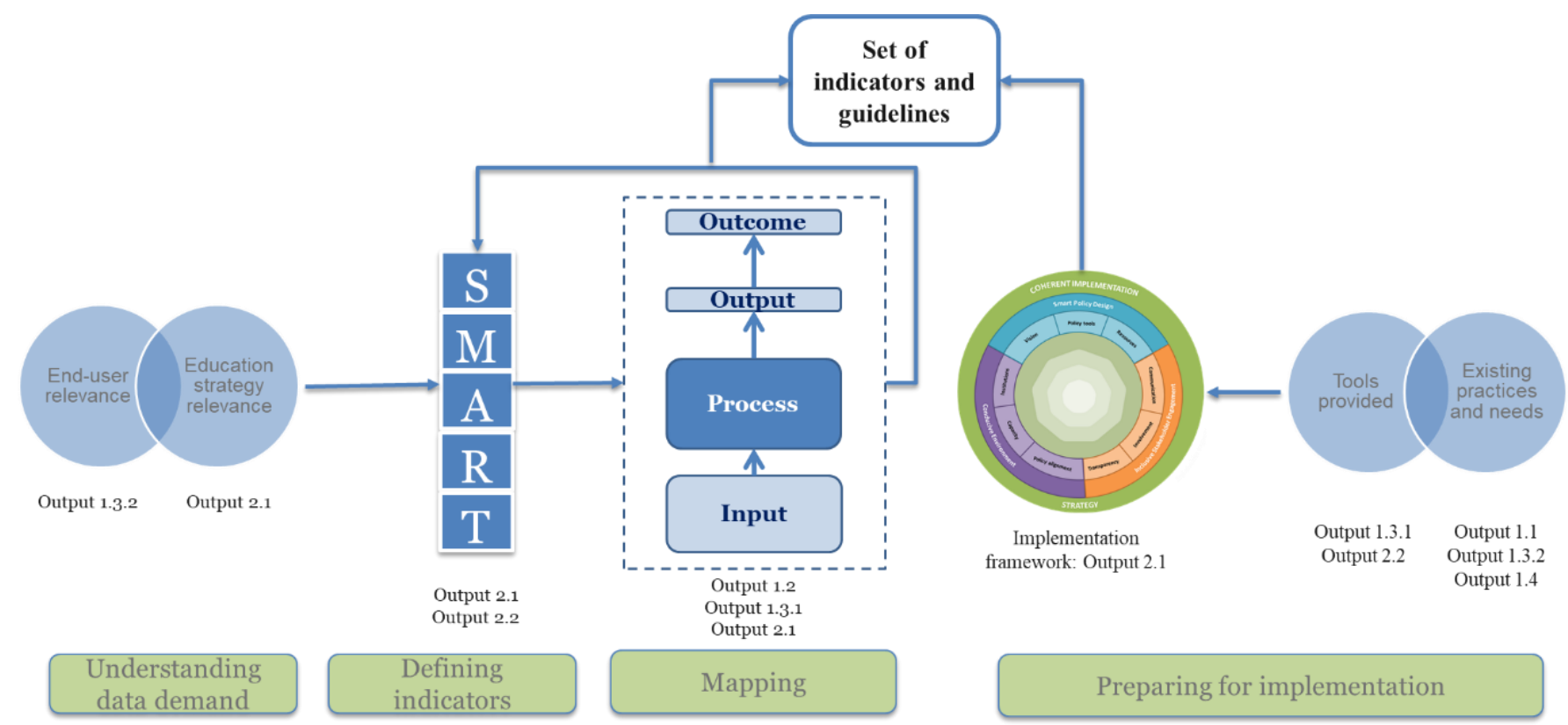

Note: a given Output (deliverable) may provide useful insight for more than one purpose.

To guide the selection of monitoring indicators for Estonia's Education Strategy 2035, the OECD team developed several custom-designed analytical tools: a strategy mapping tool, an indicators framework, and a survey on the current use of indicators by schools. These tools provide:

- Guidance on how to understand the links and sequences between the different goals and outcomes in the Education Strategy.

- Thematic analyses on objectives that are important for the MoER, but which may not be associated to a specific goal or outcome in the Education Strategy. 


\section{6 | No. 47 - Enhancing data informed strategic governance in education in Estonia}

- A mapping framework, where indicators are organised in terms of inputs / processes / outputs/ outcomes.

- Detailed information on the indicators and data that are available (or that would be needed) to monitor progress towards meeting the different objectives in the Education Strategy.

The OECD developed these tools following a review of Estonia's previous Education Strategy and draft of the new Education Strategy 2035. Selected strategic and programme indicators were evaluated according to the dimensions of a SMART (Specific, Measurable, Actionable, Relevant, and Timely) framework. In addition, the analysis ensured the indicators cover the different components of the Education Strategy, and aligned them to an input / process / output model to understand how different elements contribute to attain specific objectives.

This process has helped clarify the types of information and indicators needed to monitor the progress and achievement of the Education Strategy. In particular, it helped clarify the policy issues, education levels, and units of observation required to monitor progress with each of the outcomes, as well as potential data gaps. The data mapping exercise also helped clarify the level at which each of the outputs should and can be monitored (even if all data is then aggregated to the national level).

\section{Education monitoring in Estonia: an overview}

There is recognition that education is of central importance in shaping a knowledge society and increasing economic competitiveness. In this regard, monitoring and evaluation of education systems (also called system evaluation) has a heightened role to play, as it informs policy planning, and can contribute to education system improvement. To this end, availability of relevant information and data on education system performance at different levels is important to understand how students and education institutions perform and progress. However, data alone cannot drive performance, but it can be aligned to education strategies, educational objectives and priorities at national, regional or local level to guide those involved in the education system and focus stakeholders on the major goals and challenges in the education system as a whole.

\section{Estonia's Education Strategy 2035}

The Estonian education system is considered among the best performing systems among OECD countries, combining quality and equity in education. In PISA 2018, Estonia scored the highest in the OECD in reading and science, and the third highest in mathematics. In addition, and following PISA's definitions, Estonia has the smallest share of low achievers in all three tested subjects $(4.2 \%$ vs $13.4 \%$ on average across OECD countries), and a significantly higher than the OECD average share of top performers (22.5\% in Estonia vs $15.7 \%$ in the OECD) (OECD, 2019 $\left.9_{[1]}\right)$. Socio-economic status ${ }^{1}$ had one of the lowest impacts in the OECD on reading performance in PISA 2018, explaining 6.2\% of the variance in performance (OECD average: $12 \%$ ). As a consequence, Estonia has one of the highest share of resilient students in reading, with $15.6 \%$ of its disadvantaged students scoring among the top quarter of students in all participating countries $\left(11.3 \%\right.$ in the OECD) (OECD, 2019 $\left.9_{[1]}\right)$.

One of the main features of the Estonian education system is its decentralised governance and high degree of autonomy of local authorities (school owners): the state sets national standards and establishes principles of education funding, supervision and quality assessment. Within these guidelines, local authorities and schools have a high level of autonomy for resource allocation and curriculum (OECD,

\footnotetext{
${ }^{1}$ In PISA, a student's socio-economic status is estimated by the PISA index of economic, social and cultural status, a composite measure that combines into a single score the financial, social, cultural and human capital resources available to students.
} 
$\left.2020_{[2]}\right)$. For instance, within their schools, school directors are given full responsibility for the quality of education, financial management, appointment and dismissal of teachers, definition of teacher salaries (above a minimum) and relations to the school community and the public (Figure 3). School directors form their leadership team, and are appointed and dismissed by the school owner.

\section{Figure 3. School autonomy, Teaching and Learning International Study (TALIS) 2018}

Results based on responses of lower-secondary principals
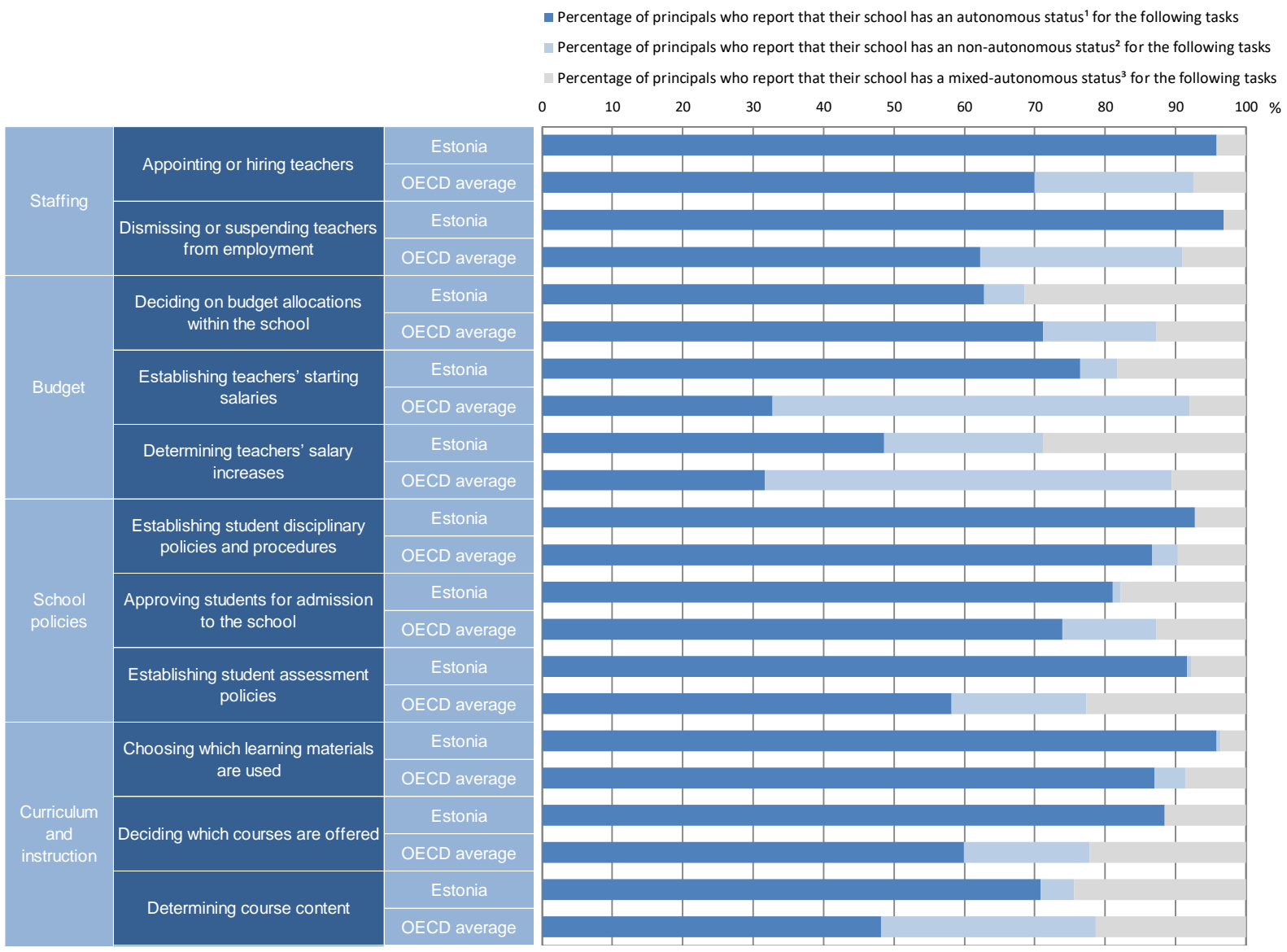

Source: OECD (2020[6]) TALIS 2018 Results (Volume II): Teachers and School Leaders as Valued Professionals, TALIS, https://dx.doi.org/10.1787/19cf08df-en

In this decentralised context, where local authorities and schools are granted high levels of autonomy, the use of relevant evidence and data is at the core of strategic education governance, and thus to the improvement of learners' experience and to the quality of education as a whole. Monitoring education is a central activity in balancing autonomy with accountability, promoting more effective and efficient policy making, and ensuring equitable and quality education for all (OECD, 2020[7]).

Against this backdrop, Estonia started developing its new Education Strategy 2035 to guide the education system. Three broad-based expert groups (values and responsibility group, welfare and cohesion group, and competitiveness group) were tasked with developing a joint vision on issues that can be influenced by the MoER's four areas of responsibility: education, research, language and youth policy. The resulting draft vision is represented in Figure 4, where the triangle at the centre encompasses the main targets for Estonian future development: happy learner, inclusive society of welfare and shared values, competitive and sustainably growing economy, and a viable and strong Estonian culture and language. 


\section{No. 47 - Enhancing data informed strategic governance in education in Estonia}

Estonia's efforts around the design and monitoring of the Education Strategy 2035 is a testament to the country's commitment to education excellence and continuous improvement. In effect, the Education Strategy exceeds strict education performance: it aims to equip the population of Estonia with the knowledge, skills and attitudes that prepare people to fulfil their potential in personal, occupational and social life and contribute to the promotion of quality of life in Estonia, as well as global sustainable development. To achieve the four-sided vision presented in Figure 4, three operational goals were formulated to shape the Education Strategy 2035:

1. Learning opportunities are diverse and accessible, and the education system enables smooth transitions between different levels and types of education.

2. In Estonia, there are competent and motivated teachers and school heads, a diverse learning environment and learner-centred education.

3. Learning options are responsive to the development needs of society and the labour market (Estonian Ministry of Education and Research, 2019 $[5]$ ).

However, to support the education system in accomplishing the Strategy, the Estonian education authorities consider that enhancing and updating the current system monitoring, including the selection of indicators underpinning the Estonian Education Strategy 2035, is required. To gear the education system in the right direction, the monitoring system is expected to provide the right information for all levels of the education system, which should strengthen data-informed decision making, and ultimately support the achievement of the goals set in the Estonian Education Strategy 2035.

Figure 4. Smart and Active Estonia 2035

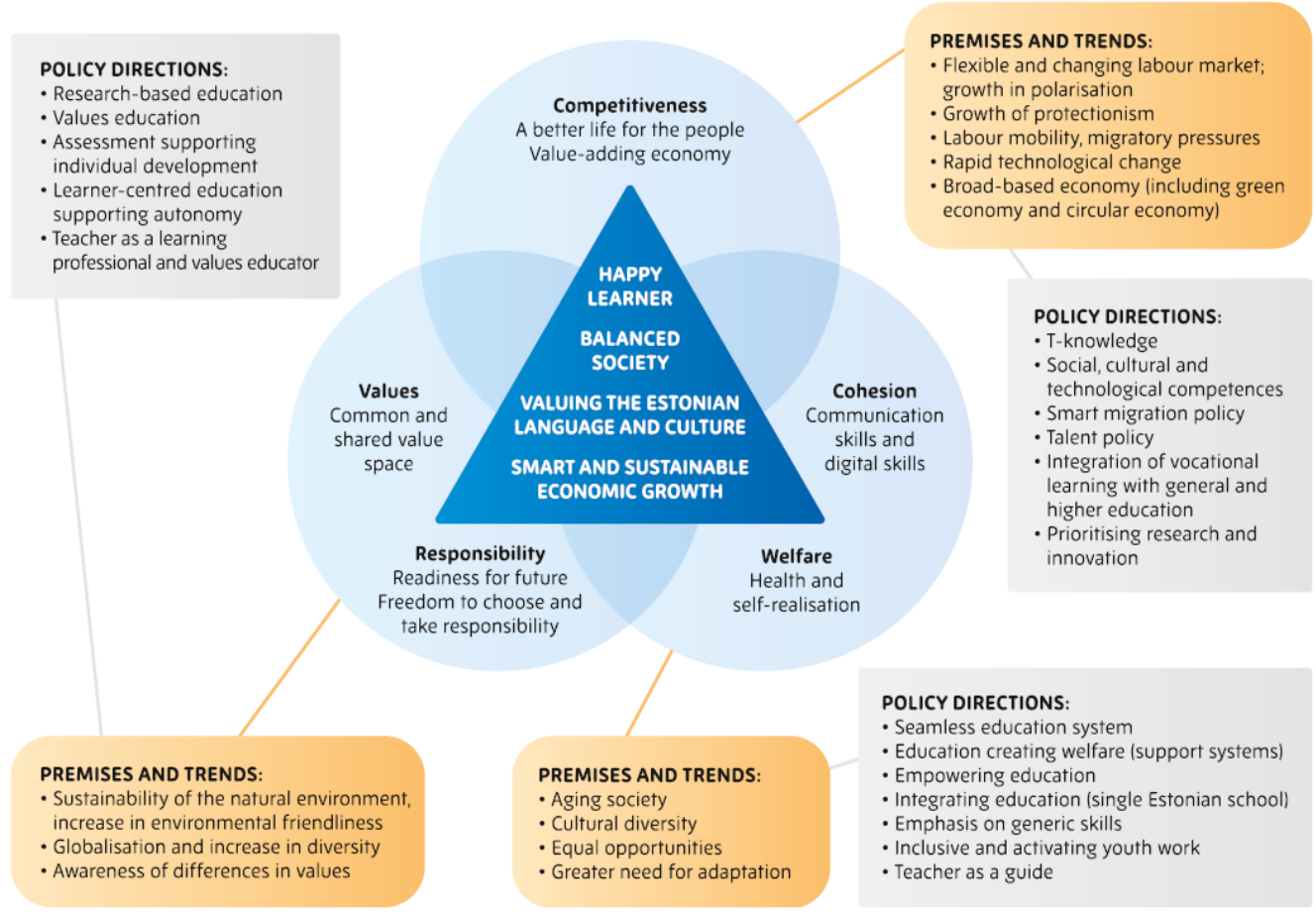

Note: Ultimate goals (in the middle), main topics (blue background), premises and trends at both personal and national level (orange background) and main policy directions (grey background).

Source: Estonian Ministry of Education and Research (2019 $\left.{ }_{[5]}\right)$, Estonian Education and Research Strategy 2021-2035: Smart and Active Estonia 2035, https://www.hm.ee/sites/default/files/tark_ja_tegus_eng_a43mm.pdf (accessed on 27 September 2021). 


\section{Estonia's education monitoring system in a comparative perspective}

In education, countries use information from a range of sources to monitor and evaluate quality and track progress towards national objectives. The effective monitoring and evaluation of the education system is central to informing policy planning for improvement, as this ensures goals and policies are rooted in evidence, helping to create an open and continuous cycle of organisational learning. In many OECD countries, independent government agencies like national audit offices, evaluation agencies, the research community and sub-national governments, play a key role in generating and using available information.

At the same time, governments need to set clear responsibilities - to determine which actors should be accountable and for what - and make information available in timely and relevant forms for transparency and public scrutiny. This provides accountability information to the public, and can help education stakeholders focus on the major goals and challenges in the education system as a whole.

According to an evaluation, or monitoring, framework proposed by an OECD project on evaluation and assessment, a number of components constitute an Education Monitoring System (EMS). First, the setting of "Goals" or aims of the EMS, defines the overarching framework for the selection of data and indicators. Second, an "Indicator Monitoring Plan" frames a comprehensive list of indicators to measure progress in achieving the goals, including the definitions and data needs. It also provides an assessment on the availability and quality of possible data sources, which will influence the selection, definitions, and methodology relative to the indicators. The third component is the "Tools" that support the EMS. It consists in national assessments that monitor performance regularly, and the Education Management Information System (EMIS), which is the data or IT related component of the EMS. The EMIS comprises the different steps of the data collection, processing, evaluation, dissemination and reporting. Finally, the last component consists in the purpose of the EMS, how it contributes to evidence-based policy making and public accountability.

Figure 5. Framework for system evaluation/monitoring

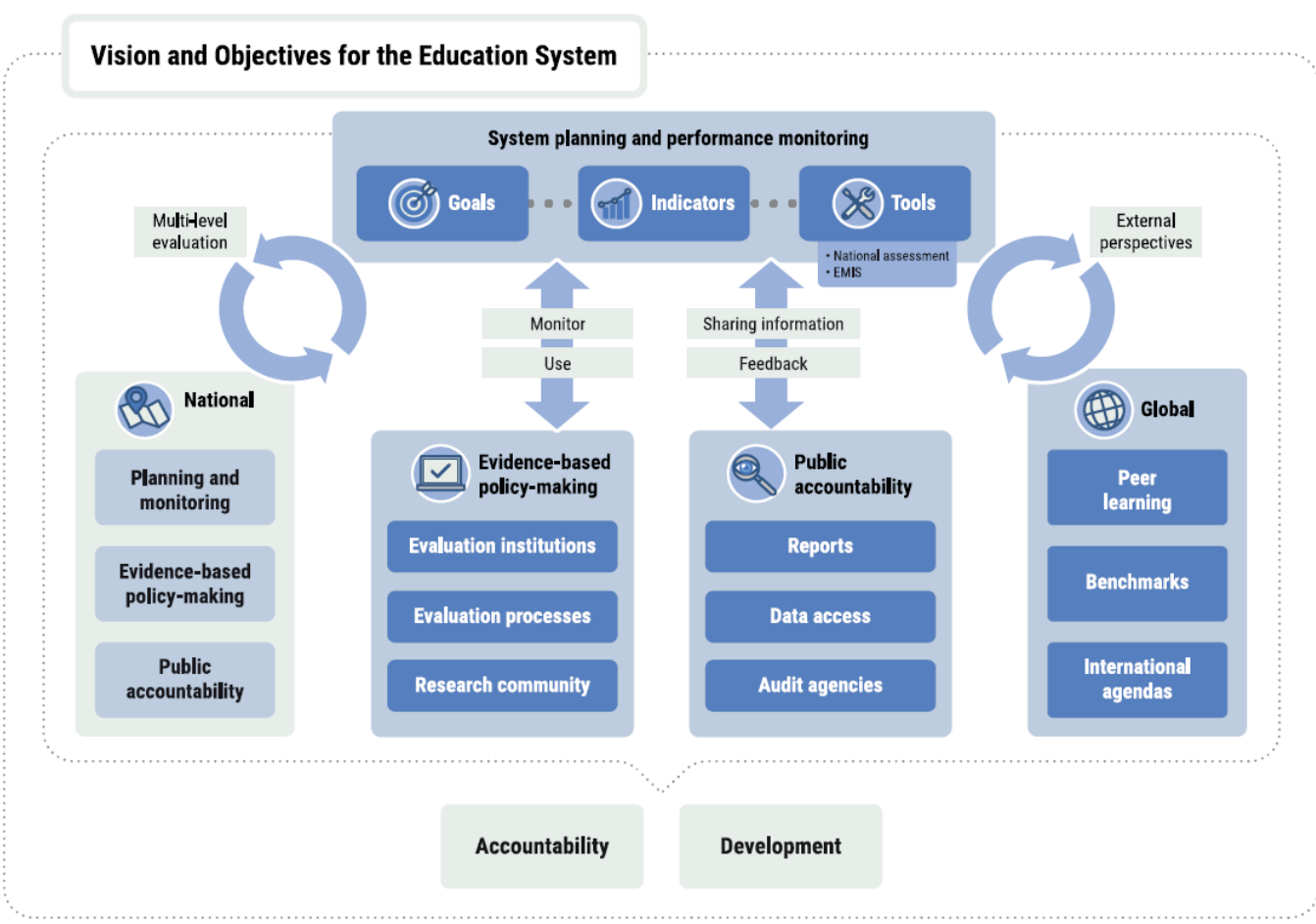

Source: OECD (2019[8] $)$ OECD Reviews of Evaluation and Assessment in Education: North Macedonia, OECD Reviews of Evaluation and Assessment in Education, https://dx.doi.org/10.1787/079fe34c-en 
As part of the "Enhancing data-informed strategic governance in education in Estonia" project, a comparative analysis of Estonia's current EMS was conducted. The project Advisory Group selected Denmark and the Netherlands as two reference countries, considering their education systems would provide valuable insights when comparing relevant EMS practices (OECD, 2020[7]). The analysis showed that:

- In highly decentralised contexts such as Estonia's, school autonomy is usually paired with robust accountability frameworks (as in Denmark and the Netherlands). In Estonia, school autonomy is built on shared responsibilities and trust, with the support of high-quality teacher profession.

- The need to renew an ageing teaching workforce in the country coupled with the Education Strategy 2035 is an opportunity to review Estonia's current EMS.

- Estonia has effective tools to support its system monitoring, such as cyclical and well-integrated national student assessments and a cutting-edge education management information system (EHIS). There is also a high level of data development capacity.

- As Estonia is currently refining its education vision for 2035, it can build on the richness of its available data and data capacity to define an indicator framework to monitor its progress. It can bring together its different indicators and data systems and develop a set of indicators that can help guide the education system and schools in the accomplishment of the education vision 2035.

- For the EMS to be useful, its indicators will need to be aligned to the Education Strategy 2035 and its policies, will need to be actionable for specific stakeholders, have coherence in relation to the context, and to allow monitoring progress towards the Strategy.

- Estonia can draw insights from Denmark and the Netherlands to review its system monitoring. The Dutch accountability framework ensures that school external evaluation, based on a careful desk-based risk analysis using school-level student performance data, results in observable steps for school improvement. The Data warehouse and the Windows for Accountability present national profiles in Denmark and growth trajectories in the Netherlands, which allow school comparison with peers (Table 1).

- Estonia can build on its strong stakeholder engagement processes to ensure that system monitoring responds to the needs of education stakeholders, especially schools, and is implemented effectively across the country.

Table 1. Summary of country comparison of education system evaluation and monitoring

\begin{tabular}{|c|c|c|c|}
\hline & Estonia & Denmark & Netherlands \\
\hline $\begin{array}{l}\text { Goals for education system } \\
\text { evaluation }\end{array}$ & $\begin{array}{l}\text { Estonian Education Act } \\
\text { Estonian Lifelong Learning } \\
\text { Strategy 2020, then Education } \\
\text { Strategy 2035 } \\
\text { National Reform Programmes } \\
\text { "Estonia 2020", then "Estonia } \\
\text { 2035" } \\
\text { European Union benchmarks for } \\
\text { education }\end{array}$ & $\begin{array}{l}\text { Folkeskole Act } \\
\text { Common Objectives }\end{array}$ & $\begin{array}{l}\text { Act on Primary Education } \\
\text { Act on Secondary Education } \\
\text { Action Plans } \\
\text { Language and Numeracy Act } \\
\text { Specific policy and programme } \\
\text { objectives } \\
\text { European Union benchmarks } \\
\text { for education }\end{array}$ \\
\hline $\begin{array}{l}\text { Responsibilities for } \\
\text { evaluation }\end{array}$ & $\begin{array}{l}\text { External evaluation department } \\
\text { of the MoER } \\
\text { HARNO (education and Youth } \\
\text { Board) }\end{array}$ & $\begin{array}{l}\text { Ministry of Education } \\
\text { School Council } \\
\text { National Agency for Quality and } \\
\text { Supervision } \\
\text { UNI-C (the Danish IT-Centre for } \\
\text { Education and Research) } \\
\text { The Danish Evaluation Institute (EVA) }\end{array}$ & $\begin{array}{l}\text { Ministry of Education, Culture } \\
\text { and Science } \\
\text { Inspectorate of Education } \\
\text { Education Council } \\
\text { Central Institute for Test } \\
\text { Development } \\
\text { DUO } \\
\text { CBS }\end{array}$ \\
\hline
\end{tabular}


No. 47 - Enhancing data informed strategic governance in education in Estonia | 11

\begin{tabular}{|c|c|c|c|c|}
\hline & & Estonia & Denmark & Netherlands \\
\hline \multicolumn{2}{|l|}{ Indicators } & $\begin{array}{l}\text { Estonia Education Strategy } \\
2035\end{array}$ & $\begin{array}{l}4 \text { global indicators } \\
\text { Database (phased out) } \\
\text { Data Warehouse }\end{array}$ & $\begin{array}{l}\text { Policy agenda indicators } \\
\text { Education Monitor } \\
\text { Equal Opportunities Dashboard } \\
\text { Drop-Out Explorer } \\
\text { Windows for Accountability }\end{array}$ \\
\hline \multirow[t]{2}{*}{$\begin{array}{l}\text { Major tools } \\
\text { to monitor } \\
\text { performance }\end{array}$} & $\begin{array}{l}\text { National } \\
\text { assessments }\end{array}$ & $\begin{array}{l}\text { National (sample-based) } \\
\text { standardised tests (years } 3 \text { and } \\
6 \text { ). } \\
\text { At the end of both basic } \\
\text { education and secondary } \\
\text { education (years } 9 \text { and 12) }\end{array}$ & $\begin{array}{l}\text { Grades } 2,4,6 \text { and } 8 \text { to monitor } \\
\text { performance. } \\
\text { Grades } 9 \text { and } 10 \text { to monitor performance } \\
\text { on school-leaving examinations and } \\
\text { transition to further education. }\end{array}$ & $\begin{array}{l}\text { The Periodical Survey of } \\
\text { Education (year 8) } \\
\text { The Annual Survey of } \\
\text { Educational Levels in (years } 4 \\
\text { and 8) } \\
\text { End-of-primary test (year 8) } \\
\text { School leavers test (year } \\
\text { depends on the educational } \\
\text { stream) }\end{array}$ \\
\hline & $\begin{array}{l}\text { Longitudinal } \\
\text { surveys and } \\
\text { databases }\end{array}$ & $\begin{array}{l}\text { The Estonian Education } \\
\text { Information System (EHIS) } \\
\text { The Estonian Examination } \\
\text { Information System (EIS) }\end{array}$ & $\begin{array}{l}\text { Student Register } \\
\text { Attainment Register } \\
\text { Population Education Register } \\
\text { Adult Education and Continuing Training } \\
\text { Register }\end{array}$ & $\begin{array}{l}\text { Longitudinal student monitoring } \\
\text { system (LVS, ParnaSys, or } \\
\text { ESIS) } \\
\text { DUO education databases }\end{array}$ \\
\hline
\end{tabular}

Note: LVS stands for Leerling Volg Systeem (Student Monitoring System) and ESIS stands for Elektronisch School Informatie Systeem (Electronic School Information System).

Source: OECD (2020[7]), Note summarising current monitoring processes, data and indicator frameworks in Estonia in a comparative perspective. https://www.hm.ee/sites/default/files/1.1. eesti hariduse seire ja hindamissusteemi vordlev analuus eng .pdf (accessed on 27 September 2021)

\section{Schools and local actors perspective on education monitoring in Estonia}

A survey of teachers, school leaders and local education administrators in a sample of Estonia's schools provided insights on current practices of data collection and monitoring at school and local level, as well as their needs (Tammets et al., 2021[9]). Some of the research findings on data use and data needs at school level included:

- Uncertain understanding of educational data concept suggests the possibility to develop resources in Estonian (and Russian) about educational data, methodological guidelines and best practices to raise the awareness of teachers and school leaders.

- While schools reported that they undertake their own surveys and find their own data to be the most relevant to monitor, there is widespread agreement on the need to integrate data collected at school and local levels with data for national purposes and systematise collection. The analysis suggested further developments of Estonia's Development Mirror conceptual framework and technological infrastructure can support school leaders' understanding of how to use existing data and own collected data in a more systematic way. In such a system, national indicators could be mapped with school-level goals and indicators combined with additional indicators that schools consider important. Collected data could be easily mapped with the indicators and used in school improvement, evaluation and planning processes.

- Teachers reported the need for a more accurate overview of their students' progress and individual student characteristics to design an efficient learning environment, but understood the ethical aspects of such data. Possible options could be to develop state level ecosystem services and analytical tools, which could help to realise personalised learning paths for students, adapt the teaching and optimise the investments to the support services.

- Schools perceived national survey data as the least relevant for school and teaching practice improvement, also because they did not feel ownership of it. It suggested that local education 
12 No. 47 - Enhancing data informed strategic governance in education in Estonia

administrators (LEAs) could communicate better on the relevance of some of the national surveys for specific school processes.

- School leaders and teachers found national strategies and indicators disconnected from and not relevant to school-level practices (planning, reporting and evaluation). Nevertheless, they would be interested in raising their competence to create meaning around national indicators for daily school management. They suggested to come up with school improvement practices (as part of some annual evaluation or planning practices) where teachers, leaders and LEAs integrate national level visions to school visions, combine national indicators with school own defined indicators, create meaning for the indicators. Schools might be supported by creating taxonomies they would follow in school improvement and evaluation processes where they first define the relevant indicators based on national strategies and then narrow down the indicators based on the school's own needs and interests.

- Four factors interact and have an impact on teachers', leaders' and LEAs' readiness to work with the data: management, collaboration, individual and data level factors.

Concluding the analysis, the report provided several suggestions to support the schools to enhance evidence-informed decision making:

- Strengthen the integration of LEAs into school improvement activities and raise the leaders' awareness of the indicators role in leadership practices. LEAs are more knowledgeable and conscious of the relevance of national strategies and indicators for school-level practices.

- Support schools to develop, in their improvement culture, the use of varied data for school improvement.

- Integrate, in teacher and school leader training, data-literacy and teacher inquiry components to support teachers to work with data, and school leaders with management processes that require the use of data. Training formats organised by Estonian universities (Tulevikukool, EduLabs teacher training model etc.) are key to support the development of inquiry mindset, data-literacy skills and raise the awareness of different data sources for different purposes.

- Integrate data on student level progress, class/course level performance and school-level processes, and consider them in perspective with strategic goals.

- Adapt, where possible, existing tools such as Haridussilm and the Digital Mirror that have value but are either not targeted or detailed enough for schools (Haridussilm, thus creating the need for schools to collect their own data), or disconnected from school improvement processes (Digital Mirror). Some adaptations, where possible, could greatly help data monitoring and evidence-based decision making in schools (such as the development and integration of the Digital Mirror to schools' ongoing management.

\section{Guidelines for effective education monitoring in Estonia}

With increased complexity, education policy makers need to take into account a large number of factors and take appropriate action to shape them into a coherent implementation strategy (Viennet and Pont, 2017 $[10])$. Based on the literature and on the OECD's work with countries, a framework was developed to support education policy implementation (Figure 6). The framework suggests that for a policy to be effectively implemented on the ground, it needs to be well designed, include stakeholders in a co-construction process while ensuring institutional coherence and capacity, and translated into an actionable strategy.

Education monitoring is a policy in itself and is tightly linked to the design of a system's education strategy and of its policies. It also depends greatly on the capacity of its stakeholders to understand, collect, and use the resulting data to enhance education. An education monitoring system holds a crucial role in an 
education system, as it contributes to facilitating effective implementation; promoting more efficient policy making; balancing autonomy with accountability in decentralised systems; and ensuring the equity and quality of education for all. When implementing an education strategy or any policy action, the monitoring system allows collecting the relevant data necessary to inform policy makers and stakeholders on implementation progress, potential issues and outcomes of the actions.

\section{Figure 6. Framework for effective education policy implementation}

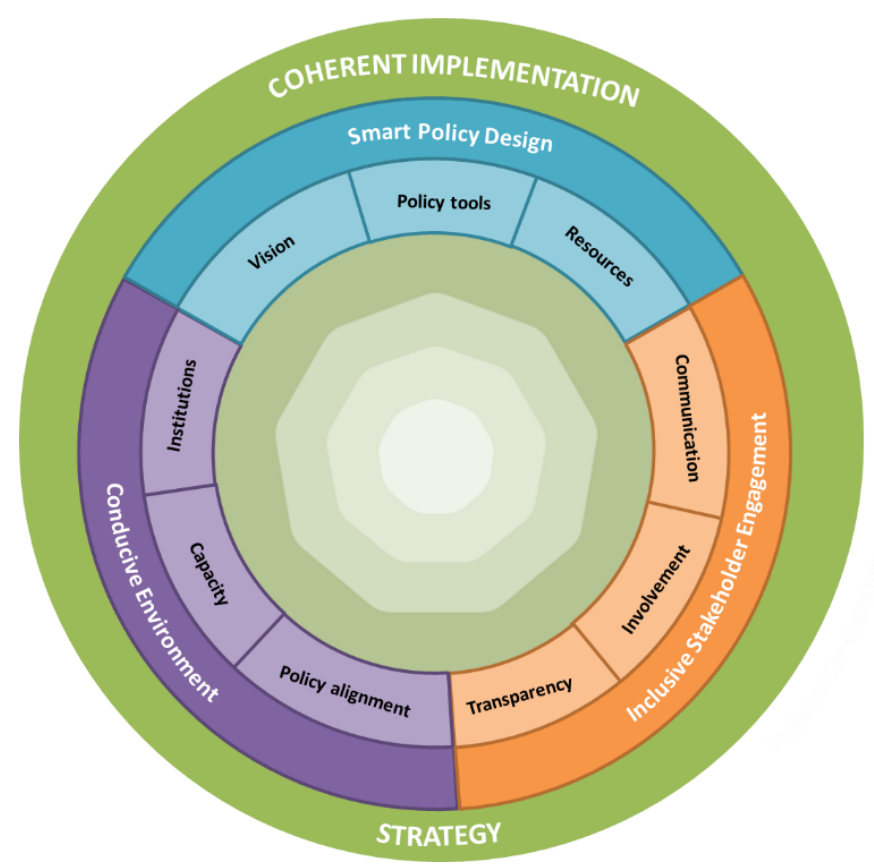

Source: OECD (2020[11]), "An implementation framework for effective change in schools", OECD Education Policy Perspectives, No. 9, https://doi.org/10.1787/4fd4113f-en.

Estonia's vision for education, as embodied by the national curriculum 2014 and outlined in the Education Strategy 2035, puts an emphasis on competences, knowledge and values, and relies on a broad set of educational objectives. Well-defined goals and objectives, linked to relevant indicators, allow for measuring progress concretely, but it is the vision that gives its overarching meaning to education monitoring. As Estonia refines the Education Strategy 2035, and develops strategic and programme indicators, it is important to revisit the vision and strategic goals to ensure the set of selected indicators reflects their scope and ambition (Gouëdard, 2021 [12]).

The OECD team analysed the Education Strategy 2035 and its associated indicators from an implementation perspective. Reaching the goals in Estonia's Education Strategy 2035 will largely depend on the country's capacity to select, retrieve and analyse relevant data to inform stakeholders' decisions, and on the way actions are taken based on this information. In that sense, the EMS plays a critical role in achieving Estonia's vision for education, as it provides the means to enhance data-informed strategic governance.

This section presents a set of guidelines for effective education monitoring in Estonia, based on the implementation of the indicators associated with the Education Strategy 2035. These guidelines are grounded on the evidence gathered from international analysis, discussions with stakeholders about current and future education indicators, and the analysis of Estonia's approach to education monitoring conducted throughout the project. In particular, the guidelines build upon several activities performed for the Estonian Ministry (see Figure 2 and Annex A): 
14 No. 47 - Enhancing data informed strategic governance in education in Estonia

- Survey of monitoring practices and data needs at school level.

- Suggestions for effective use of the mapping tools for strategy, indicators and data sources, and tools for indicator-related analysis.

- The OECD framework for effective education policy implementation, which highlights the links between education monitoring and the success of policy implementation.

\section{The Education Monitoring System (EMS) and indicators need to be aligned to the strategy and its vision}

Education monitoring should be driven by the Strategy's vision. As a roadmap for Estonia's education, the Education Strategy 2035 and the vision it offers forms the basis for the development of a comprehensive and coherent set of indicators. This vision is what gives meaning to education monitoring, while the strategic goals, objectives and action trajectories set out in the Strategy further guide monitoring processes to measure concrete progress on the various indicators. One indicator by itself does not provide enough information for a decision maker. Conversely, the indicators and the data they help collect should be constantly analysed in relation to the Strategy's vision.

Indicators need to be aligned to the Strategy's targets, challenges and actions: this alignment is a pre-requisite for sound implementation as it ensures coherence in the objectives of the education monitoring system. However, the mapping exercise of the strategy revealed a number of gaps in the alignment of challenges to actions; and between challenges and indicators (OECD, 2020 [13]). Some challenges appear misaligned with regards to their target (e.g. the challenge on "the share of instruction in English has increased rapidly in higher education, while the share of instruction in Estonian has decreased actions" seems more related to Strategic Goal 2 and its Action Trajectory 2.3 on ensuring high-quality instruction in Estonian, than to Strategic Goal 1). Similarly, some actions do not seem to address any of the challenges (for example, there is no challenge specific to well-being of students, although some actions address this).

Furthermore, it is important that the indicators reflect the richness of the country's vision. Estonia's future-oriented vision requires indicators that go beyond students' literacy and numeracy, and teachers' salary. Existing indicators related to students' information and communications technology (ICT) competencies, mobility and individuals' well-being are promising. In addition, Estonia has already begun to think of such indicators that seek to assess the development of skills, such as self-directed learner.

The education monitoring system may be considered as a tool that operationalises the goals of the Estonian Education Strategy. It enables a holistic understanding of the interconnections across each of them, where each goal influences the realisation of the other two, also presented in the Excel file (Indicator selection). For example, for diverse learning opportunities and smooth transitions across levels of education (Goal 1) to occur, there must be motivated and competent teachers (Goal 2). Similarly, the effectiveness of what students learn and what they can do with what they learn should reflect the needs of the labour market (Goal 3). At the same time, both Goals 2 and 3 also result directly from the performance of Goal 1: students' learning and social outcomes (Goal 1) will support their capacity to integrate into the labour market (Goal 3) and should influence teachers' teaching and pedagogical practices (Goal 2). Put differently, all Goals are interrelated, the fulfilment of one depending on that of the other two. In the centre, where the three goals overlap, is the culmination of Estonia's Education Strategy: to produce individuals that are equipped with the knowledge, skills and attitudes that help them fulfil their potential and contribute to quality of life and society in Estonia (General Objective).

Within each goal, the action trajectories are also connected and influence one another. For example, when learners are supported (Action Trajectory 1.2) and their learning environment supports their physical and mental well-being (Action Trajectory 2.5), learning becomes a positive experience which contributes to higher access to education (Action Trajectory 1.1) and reduced drop-out rates (Action Trajectory 1.2). 
When students participate in school, then the effectiveness of learning increases across a range of disciplines for all students (Action Trajectory 2.1, 2.2, 2.3, 1.2). A positive cycle follows, as improved education outcomes brings on higher social and emotional skills and feelings of well-being which contribute to nurturing a positive learning environment (bringing us back to Action Trajectory 1.2 and 2.5).

The connections modelled in Figure 7 have guided the definition of indicators to ensure a holistic representation of the different elements of Estonia's education strategy and a deep understanding of the determinants of educational performance.

Figure 7. Strategic interactions of the goals and action trajectories of the Estonian Education Strategy

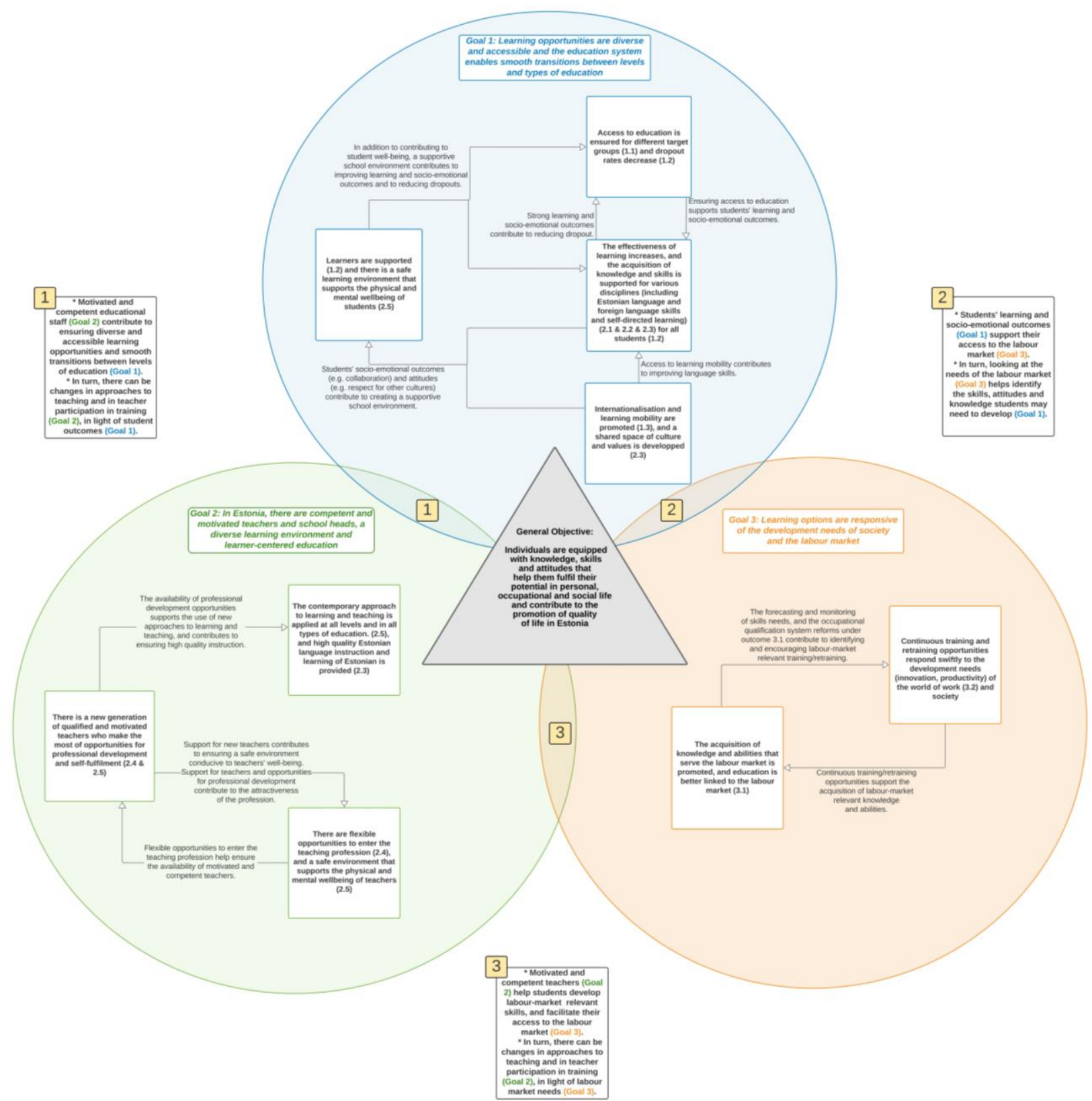

Source: OECD $\left(2020_{[14]}\right)$ Analytical tools for education strategy mapping and their technical note for future uses by the MoER, OECD $\left(2021_{[15]}\right)$ Proposal for a coherent set of indicators and guidelines for education monitoring 


\section{Indicators need to be relevant to stakeholders who will be using them}

Overall, for the Education Strategy 2035 to be implementable, it is important to consider how the indicators will engage the professionals in schools, and in adult learning more broadly, to take concrete actions towards the achievement of objectives. These indicators can be used to provide information for those involved in accomplishing the specific objectives of the strategy and to monitor progress with it at a higher level.

To help clarify the link with specific actions of the strategy, and identify who can be responsible for acting upon those indicators, an implementation category has been included in the indicator review framework. It highlights how the information conveyed by indicators could be used in the system for improvement (OECD, 2020[13]).

However, if the strategy aims to drive engagement among schools, teachers and school heads, then it would be important to ensure that indicators commonly used to monitor performance at school level are also included in the main set of indicators. In the Education Strategy 2035, most of the indicators are designed from a national or regional monitoring perspective, and are therefore less relevant or actionable at school level. The school leaders and teachers consulted in Estonia perceived national indicators as far from the reality of school's daily operations (Tammets et al., 2021[9]). They were interested in working with national authorities to translate national indicators into something they may relate to and use as part of school improvement processes. In particular, they highlighted the necessity to understand better their students' needs to target more effectively appropriate teaching and pedagogical approaches.

\section{Coherence should be maintained between indicators}

Indicators should cover all components of the indicator framework (input, process, output), to allow for a holistic analysis of the determinants of educational performance. Most of the indicators currently in the Education Strategy 2035 are markedly output oriented. While this provides information on the final performance of education systems, it has limited information or contributions on the conditions that have led to this result. Such indicators confirm trends, but inform in real time neither about the types of practices, people, strategies, materials, or technologies currently in use, nor about how to act upon them to improve education outcomes and monitor implementation (Gouëdard, 2021[12]).

In addition, it is important that the policies included in the strategy are aligned (OECD, 2020[11]), and the indicators associated with the strategy should reflect this coherence. When building an indicator system, there may be considerable overlap among policies and indicators. This requires adopting a whole-of-system perspective to review carefully the indicators in relation to the different objectives introduced in the strategy. This analysis may help identify potential repetitions, lack of data coverage, and potential gaps in indicators.

\section{Indicators are actionable if their link to the strategy is clear}

The clearer a strategy is in terms of objectives and actions, the more likely stakeholders will use it widely. To be clearly understood, indicators should be streamlined and overlap across different targets avoided. For example, in the Education Strategy 2035, general objective indicators are also relevant to each of the strategic goals, but they are set apart. This weakens the connection between the two, and limit the potential of general objectives indicators to drive change. It could be more efficient for monitoring and communication purposes to distribute the general objectives indicators in the relevant strategic goals. In addition, similar indicators (though with different breakdowns) are mentioned in different parts of the strategy. For example, top-performing students in PISA is considered a general objective, while low-performing students are considered to address the second Strategic Goal on Teachers. It is unclear why top-performing students would not also be considered to address Strategic Goal 2. 
A number of indicators in the Education Strategy 2035 also relate to overall system accomplishments loosely connected to the specific policy actions included in the Strategy. These indicators refer to general outcomes such as drop-outs in tertiary education and employment rates, which are difficult for schools, teachers and principals to act upon directly. An actionable indicator means that "those using the indicator have the power to act on the results to produce the desired change, and the results are produced in such a way that calls to action" (Gouëdard, 2021, p. 33[12]). This implies not only that the indicator produces information relevant to stakeholders as reviewed in the previous section, but also that this indicator is clearly connected to a strategy's objectives and provides clear incentives to take action towards their realisation.

\section{A coherent set of indicators for education monitoring in Estonia}

This section first presents two key frameworks for indicator definition and selection to inform future developments of Estonia's education monitoring system. Then, building on these frameworks and the indicators selection guidelines detailed in the previous section, this section outlines the most appropriate indicators identified to monitor progress on the action trajectories of each of the three Strategic Goals of Estonia's Education Strategy 2035.

When selecting indicators, attention was provided to ensure indicators were relevant at school level, and to reach a proper balance between input, process, and output indicators. The following points were considered for the selection and mapping of indicators to the strategy:

- Actions that were specific, measurable and could be translated into a SMART indicator were prioritised. The indicators selected are those that can best measure progress on Estonia's education strategy and address schools' needs as defined through previous outputs of this project. To ensure adoption of the education monitoring system at all levels of the Estonian education system, particular attention was provided to indicators that are meaningful for teachers and school leaders, as well as to stakeholders responsible for setting education policy.

- Some actions of the strategy remain broad, and include abstract concepts that cannot easily be quantified and would not be appropriate for indicator monitoring. In many cases, these actions may be considered as a pre-requisite for the successful completion of other actions, where alternative and qualitative evaluation mechanisms are likely to be more effective and cost-efficient to track progress than quantitative indicators. In some cases and where relevant, an indicator on the expected result of the action may be proposed instead.

- For example, government mandates for the provision of education close to home either exist or not. While an indicator on their existence may be developed, its binary nature does not necessarily lead to impactful policy action that aligns with the education strategy. In such cases, indicators on the intended results of the action are proposed instead. Here, this may be the average distance students travel to access the nearest school. While this approach makes the indicator more actionable, it also changes its interpretation, as the action becomes one of the many inputs that may influence its result. In this example, a high average distance to travel for school may be the result of the inadequate setting of mandates, but other factors may also come into play. The relationship across actions of the Education Strategy 2035 is illustrated in details in the input / process / output framework.

- Actions of the strategy that encompass multiple and different concepts may be monitored by more than one indicator.

- Similarly, one indicator may serve more than one action through its disaggregation and breakdowns. Each breakdown may address different actions, sometimes located in different goals. For example, the attainment indicator, which measures the highest level of educational achievement, can be broken down according to different attributes such as age, gender, 
socio-economic status, language spoken at home, etc. It can therefore be used to monitor the general attainment of the population, but also the share of adults enrolling in professional programmes (breakdown on programme orientation), the share of young 18-24 year-olds that have left education without completing upper-secondary level (breakdown by age and educational attainment), or the general attainment level of vulnerable population groups (breakdown by special education needs, migrant, or socio-economic status). Where relevant, the specific breakdown required for a given action is highlighted in this section.

Once this mapping was complete, the indicators were then further prioritised and narrowed down to 22 core indicators, that can contribute to the effective implementation of the Education Strategy 2035. These 22 indicators have been selected among strategic indicators, programme indicators and additional indicators proposed to satisfy both data requirements from the Strategy and data demands from end-users. These indicators are highlighted in bold blue in each of the tables. The indicators are assessed and designed based on two frameworks, presented below and in the Excel file Indicator selection:

- the SMART framework: specific definitions of the indicator and breakdowns considered, measurement and calculation methodology, actionability at each of the levels of the education system considered (national, local and school), relevance and connection to the action trajectories of the Estonian Education Strategy, and recommended timeliness and frequency of the indicator.

- the framework mapping indicators in terms of inputs, processes and outputs.

Data availability was not considered as a necessary condition for the selection of indicators from the onset but rather as a parameter in the design of the education monitoring system that enables the tracking of key performance indicators. Therefore, a gap assessment between the data needs of proposed indicators and existing data was conducted. Where data did not readily exist, proposals to design new data collection instruments or to adjust current ones have been made.

Indicators that have been identified as relevant for the Estonian strategy but that have not been prioritised are presented in italics in the tables of this section. A final section entitled "Summary of the proposed set of indicators" brings a holistic view to all proposed indicators, detailing their level of actionability and presenting some suggestions to address existing data gaps.

\section{SMART assessment of selected core indicators}

This framework, used by the OECD INES team in its education data analysis, served as a basis for the indicator review (OECD, 2020[13] $)$, and was presented at a capacity-building workshop (OECD, 2020[16]). According to the SMART framework, indicators should be:

- Specific: The definition of the indicator should be clear, with the appropriate level of disaggregation specified.

- Measurable: The indicator should have the capacity to be counted, measured, analysed or tested.

- Attributable/Actionable: The indicator should allow targeted stakeholders to act on their results.

- Relevant: The indicator must be a relevant measure of the desired outcome or goal for both end-users and in relation to the Strategy.

- Timely/Time-bound: Indicators must reflect the timing of the data collection and should track progress at regular frequency within a set time period.

In order to evaluate the specificity, measurability and timeliness of indicators, the analysis has been based on the initial indicator review (OECD, 2020[13]). To assess how relevant and attributable/actionable indicators are, the analysis has also reviewed where data requirements from end-users intersect with the outputs of the Education Strategy 2035. This was done by comparing the results of a purposely designed survey of school leaders, teachers, and local education administrators (Tammets et al., 2021[9]), with the 
mapping of strategic and programme indicators to actions and challenges of the Education Strategy 2035 (OECD, 2020[13]).

From this analysis, 22 indicators (highlighted in bold blue) have been prioritised based on their relevance towards monitoring education progress as stipulated in the Education Strategy 2035. The indicators were also selected based on their actionability by various actors within the education system, and in particular, actors within schools. Finally the selection of indicators was also driven by their capacity to provide a holistic analysis of the determinants of educational performance across inputs, process and outputs. This last point is elaborated in the next section of this note. Each of the 22 prioritised indicators has been designed and detailed according to the dimensions of the SMART framework listed in Section 2 and presented in detail in the Excel sheet Indicator selection. The SMART assessment describes the indicators following their recommended characteristics and design features, based on internationally agreed concepts, definitions and methodologies.

A number of these 22 indicators were already included among the global and strategic indicators proposed by Estonia and which the OECD team commented on (OECD, 2020 $\left.{ }_{[13]}\right)$. Following their SMART assessment, a few adjustments to the definition and methodology of these indicators is proposed:

- Including a breakdown by socio-economic status. Although Estonia is one of the OECD's strongest performers when it comes to ensuring equitable learning outcomes across students from different socio-economic status, it is still important to track progress on this dimension over time. This does not relate only to educational performance. Estonia's Education Strategy 2035 also endorses that all learners should have access to vocational and higher education regardless of their socio-economic situation (action 1207) and equity is at the heart of the three goals of the Education Strategy 2035. Socio-economic status can be measured in different ways.

- In the OECD's Programme for International Student Assessment (PISA), a student's socio-economic status is estimated by the PISA index of economic, social and cultural status (ESCS), a composite measure that combines into a single score the financial, social, cultural and human-capital resources available to students. In practice, it is derived from several variables related to students' family background that are then grouped into three components: parents' education, parents' occupations, and an index summarising a number of home possessions that can be taken as proxies for material wealth or cultural capital, such as possession of a car, the existence of a quiet room to work, access to the Internet, the number of books and other educational resources available in the home (OECD, 2019 ${ }_{[17])}$.

- When the design of educational monitoring systems involves longitudinal information systems then connections with other databases may also provide relevant information on student characteristics such as the income level of the household.

- Including a breakdown on language spoken at home: Estonia's education strategy places a strong emphasis on ensuring a common Estonian culture, in particular among those who may not speak Estonian at home. A breakdown by language spoken at home would enable a more effective monitoring of these population groups than a migrant status, by focusing on language as an enabler of education performance and integration in society.

- Monitoring the participation in education of children since the age of 3: The initial indicator focused on the participation of students aged 4 to school age participating in pre-school. There is growing evidence on the importance of participation to early childhood education and care from a very young age, and the recommendation is therefore to extend this indicator to children of age 3 until the start of kindergarten. We would suggest this indicator focuses on ensuring access to education to as many young children as possible, given the benefits of early schooling on children's cognitive and emotional development, rather than seeking to understand the development of those not enrolled. The latter may be difficult to implement and derive concrete actions for education professionals to act upon. 
- Expanding the indicator on drop-out rate to include the concept of grade/level completion: While an indicator on drop-out is very relevant at local and national level, schools cannot themselves differentiate between a student that leaves the school but remains in the educational system, compared to someone who leaves the school and the educational system. Furthermore, indicators on completion or grade repetition can serve as leading indicators to warn schools of the risk of student disengagement and drop-out. To increase the relevance and actionability of this indicator at school level, it is recommended to increase its coverage to completion and repetition, in addition to drop-out. A further disaggregation to understand the share of students that graduate from a different programme than the one they entered in would also provide information on the flexibility of pathways and the ability of students to transition from one to the other.

- Measuring entrepreneurship as a combination of different indicators: Entrepreneurial competencies are defined as knowledge, skills and attitudes that affect the willingness and ability to perform the entrepreneurial job of new value creation (Martin Lackéus, 2015 ${ }_{[18]}$ ). Therefore, entrepreneurial capacity can be measured through a combination of indicators, such as educational attainment in certain fields of study (knowledge), collaborative problem solving or creativity (skills), global competencies or capacity to develop a growth mindset (attitude) (Gouëdard, 2021 [19]; OECD, $2021_{[20]}$ ), among others.

- Adding additional sub-indicators for more precision: Some sub-indicators have been added when their methodology provides additional precision to the matter at stake. For example, while the indicator on teacher salary follows the current methodology used in Estonia to compare teacher salaries with the national average income, a comparison relative to the adults with the same educational attainment as teachers would more reflect more strongly on the attractiveness of the teaching profession.

In addition, nine of the indicators proposed among this list are new, derived from the insights gathered from the various outputs of this project and the feedback of diverse actors of the Estonian education system, and based on indicators and assessments developed from internationally agreed concepts, definitions and methodologies.

For each indicator proposed, an assessment of the data gaps was carried out, with the following suggestions:

- The data already exists: there is no gap but rather a recommendation to make use of the existing data to address the needs of different stakeholder groups and respond more effectively to the goals and action trajectories of Estonia's Education Strategy.

- Integrate the proposal in already existing national data collection instruments: This is often recommended for new questions that align to the main objective of an already existing survey but that seek to quantify a novel aspect of the topic through additional questions or breakdowns, to target a new stakeholder group, or to increase the timeliness of the data if the initial source was an international survey. For example, questions on the effectiveness of teacher practices, inspired by the OECD Teaching and Learning International Study (TALIS) conducted every five years, may be integrated in the existing annual national teacher satisfaction surveys. Similarly, these teacher satisfaction surveys may be extended to school heads to gain their perspective on their profession.

- Create a new data collection: For the indicators inspired by the PISA innovative domains (global competency or collaborative problem solving), different options would need to be considered as there are no immediate plans for these domains in upcoming cycles. The innovative domains are composed of a cognitive assessment and a student questionnaire. While the student questionnaire can easily be implemented in existing or new national survey mechanisms, implementing similar cognitive assessments nationally would require more resources. Alternatively, Estonia may use the five additional questions offered to countries participating in PISA to introduce some of the most relevant questions from these domains to be administered at national level. The OECD PISA team 
is ready to support Estonia in identifying the most appropriate course of action and implementing these assessments at more regular intervals as needed.

\section{The input / process / output / outcome framework}

This framework was initially developed in support of the mapping work performed on the 2014-2020 education strategy $\left(\mathrm{OECD}, 2020_{[14]}\right)$, and was later adapted for the indicator review of the 2035 strategy (OECD, 2020[13]). This framework aims at providing a holistic analysis of the determinants of educational performance, by organising indicators in terms of inputs, processes and outputs. This tool helps map the levers that contribute to the achievement of the different goals in the strategy and therefore helps identify the indicators needed (or lacking) to monitor progress. The definitions are as follows:

- Input: Measure of a policy action that can be directly changed by the actors in order to facilitate the process (e.g. financing and/or creation of teacher training programmes).

- Process: Measure of the participation of actors in the process, especially thanks to the existence of the input (e.g. participation in teacher training programmes).

- Output: Measure relating to the link between the input + process and the outcome (e.g. training is useful to improve teaching in classrooms).

- Outcome: The ultimate goal that is expected to occur if all the outputs are reached (e.g., teachers are well prepared and good at their job). In this case, the outcome is the accomplishment of the action trajectories established in the strategy (e.g. Action Trajectory 2.5: Ensuring a new generation of heads of schools, supporting their professional development, and developing and implementing an assessment system for heads of schools in order to promote educational innovation and create a safe learning environment that supports the physical and mental well-being of all).

By presenting indicators in terms of inputs / processes / outputs / outcomes, this framework identifies where an issue may emerge from when a strategic goal is not reached. More precisely, it helps understand whether it may be due to a lack of input (e.g. lack of funding or infrastructure), a lack of use (e.g. low participation in a programme) or a lack of quality/usefulness. (e.g. low completion). This framework also provides a clear understanding of the interplay across the different indicators, and therefore identify the levers that may be actioned to improve a given outcome or model certain scenarios.

Two tools have been developed for this analysis, both displayed in the Excel file Indicator selection:

- The mapping of indicators in terms of strategic goals, and in terms of input, process, outputs and outcomes of the Estonian Education Strategy. The outcomes to be achieved have been selected from the related action trajectories of the strategy.

- The schematic display of how the goals and outcomes of the Estonian Education Strategy relate to each other, and therefore how the indicators may be used to gain a holistic understanding of what influences progress toward meeting education objectives. 


\section{Box 1. Application example of the input / process / output / outcomes framework}

While the input / process / output / outcomes framework can be read in different ways, it takes on its full meaning when starting from the outcome and moving backwards through the chain to output, process, and finally input. This ensures the end goal is always kept in mind and maintains the logical sequence of what may be influencing its result. For example, the first set of indicators used to monitor the "Goal 1 of the Estonian strategy: Learning opportunities" are diverse and accessible and the education system enables smooth transitions between levels and types of education.

- The outcome displayed in Action Trajectory 1.1 "Ensure access to education for different target groups" and 1.2 "reduce drop-out rates" can be measured by the output indicator Educational attainment and its sub-indicator Percentage of 18-24 year-olds not in education or training.

- This in turn will be influenced by the two process indicators: Pre-schooling and the Completion / Drop-out rate.

- These process indicators are in turn influenced by the inputs injected into the system, in this case, Expenditure in education.

This framework also illustrates how the performance on national indicators in fact derives from the performance of indicators at school level. In the example above, the output indicator Educational attainment and its sub-indicator Percentage of 18-24 year-olds not in education or training are actionable at National and Local level, yet their targets can only be achieved if students successfully transition from one grade to the next in schools. In other words, performance on the completion rate at school level will help achieve the national goal in educational attainment. Similarly, teacher retention, an output indicator monitored at National and Local level, will depend on teachers' satisfaction with their conditions and environment at the school in which they teach, which can be captured in part by the input indicator teaching profession valued in society. The relationship also works in reverse where the result of indicators at national level may also influence what happens at school level. For instance, the indicator on Expenditure in education, monitored at national or local level, will influence the resources invested in teaching, and in particular the indicator on education personnel practices monitored at schools.

Translating the Estonian Strategy in meaningful indicators for schools has been a challenge for Estonia (OECD, 2020 ${ }_{[14]}$; Tammets et al., 2021 $\left.{ }_{[9]}\right)$. The distinction between the levels of monitoring of indicators should not be viewed as silos, but rather as different components of a common monitoring framework that all contribute towards the fulfilment of the national education strategy. Leveraging the concepts in the input / process / output framework translates in concrete terms how monitoring what happens at school level contributes to the achievement of indicators at national level and how decisions made at national level may influence results within the school. 


\title{
Strategic Goal 1: Learning opportunities are diverse and accessible and the education system enables smooth transitions between levels and types of education
}

\author{
Action Trajectory 1.1. Ensuring a school network and infrastructure characterised by the \\ provision of high-quality education, inclusiveness and efficient use of resources to ensure \\ access to education for different target groups and a learning environment that supports \\ contemporary approaches to learning and teaching.
}

Table 2. Indicators mapped to Action Trajectory 1.1

\begin{tabular}{l} 
Action \\
\hline $\begin{array}{l}\text { 1101-mandate local authorities to ensure pre-school } \\
\text { education close to home. }\end{array}$ \\
1102-more clearly define the distribution of \\
responsibilities at the level of upper-secondary \\
education by giving more responsibilities to the \\
government and continuing the consolidation of the \\
network of upper-secondary schools. The \\
clarification of responsibilities includes the \\
specification of funding system and performance and \\
quality framework at the pre-school, basic and \\
upper-secondary levels of education.
\end{tabular}

1103-mandate local authorities to ensure the provision of basic education close to home at least at the first and second stage of basic school. In regions with declining populations, concentrate the provision of lower-secondary education to larger centres, providing, where appropriate, services to support participation, such as transport.

1104-develop and implement the concept of regional education centres in order to create new forms of study and opportunities for linking general, vocational and higher education and non-formal learning, including youth work, and facilitating transitions.

1105-develop centres of excellence for professional fields.

1106-ensure optimal number of vocational and higher education institutions.

1107-ensure that infrastructure and premises should meet the requirements of contemporary approaches to learning and teaching, taking into account the principles of energy efficiency.

Indicator $\quad$ Recommended

Pre-Schooling (by region)

The share of students who attend a school within a given National, Local $\mathrm{km}$ radius from their homes.

The distribution of responsibilities is a pre-requisite for the successful completion of other objectives, but is not a quantifiable metric in itself. It may be proxied to some extent by the indicator on Expenditure in education (expenditure per student and share of current/capital expenditure by region), although financial responsibility is only one of the levels of decision making.

National, Local

While no indicator is proposed to specifically monitor the distribution of responsibilities at all levels, it is important to periodically take stock of the progress of this action through qualitative assessments.

This action is a pre-requisite for the successful completion of other objectives, but is not a quantifiable metric in itself. Its result may be monitored by an indicator on:

The share of students who attend a school within a given National, Local $\mathrm{km}$ radius from their homes.

In addition, it is important to periodically take stock of the progress of this action through qualitative assessments.

The implementation of the concept of regional education centres is a pre-requisite for the successful completion of other objectives, but is not a quantifiable metric in itself. While no indicator is proposed to monitor this action, it is nevertheless important to periodically take stock of its progress qualitatively.

The number of centres of excellence for professional fields in Estonia over time.

The optimal number of vocational higher education institutions is a pre-requisite for the successful completion of other objectives, but the concept of how the optimal number is defined should be specified whether this is based on geographical, functional, or other considerations - in order for an indicator to be developed.

No indicator is proposed to monitor this action, as the notion of "requirements of contemporary approaches to learning" is very broad, and does not allow for effective monitoring. 


\title{
24 No. 47 - Enhancing data informed strategic governance in education in Estonia
}

\author{
Action Trajectory 1.2. Ensuring flexible learning opportunities, accessibility of high-quality \\ education and supported learning in order to reduce drop-out rates and to exploit \\ everyone's full potential.
}

\section{Table 3. Indicators mapped to Action Trajectory 1.2}

\begin{tabular}{|c|c|c|}
\hline Action & Indicator & $\begin{array}{l}\text { Recommended } \\
\text { monitoring level }\end{array}$ \\
\hline $\begin{array}{l}\text { 1201-improve the capacity of kindergarten heads to } \\
\text { identify special educational needs early and to } \\
\text { provide high-quality support services to children } \\
\text { under school age. }\end{array}$ & $\begin{array}{l}\text { The percentage of children enrolled in kindergarten with } \\
\text { special needs receiving targeted support, or the } \\
\text { percentage of staff receiving targeted training on special } \\
\text { education needs. }\end{array}$ & $\begin{array}{l}\text { National, Local, } \\
\text { School }\end{array}$ \\
\hline $\begin{array}{l}\text { 1202-create conditions for smooth and flexible } \\
\text { transitions between different levels and types of } \\
\text { education as well as to the labour market (greater } \\
\text { coherence between pre-school and general } \\
\text { education; a single upper-secondary education } \\
\text { standard), including creating conditions and } \\
\text { opportunities for learners to acquire education in } \\
\text { smaller modules (bitesize learning) tailored to the } \\
\text { needs and abilities of each learner; }\end{array}$ & $\begin{array}{l}\text { Completion / drop-out rate and Employed recent } \\
\text { graduates. } \\
\text { No indicator is proposed regarding the opportunities for } \\
\text { learners to acquire education in smaller modules, given } \\
\text { the concepts are not easily quantifiable. While no } \\
\text { indicator is proposed to monitor this action, it is } \\
\text { nevertheless important to periodically take stock of its } \\
\text { progress qualitatively. }\end{array}$ & $\begin{array}{l}\text { National, Local, } \\
\text { School for } \\
\text { Completio/Drop-out } \\
\text { rate } \\
\text { National/Local level } \\
\text { for Employed recent } \\
\text { graduates }\end{array}$ \\
\hline $\begin{array}{l}\text { 1203-develop a comprehensive solution for taking } \\
\text { non-formal and informal learning into account in } \\
\text { formal education in order to give more consideration } \\
\text { to the knowledge and skills acquired in various } \\
\text { environments (digital environment, workplaces, } \\
\text { museums, youth centres and programmes, hobby } \\
\text { schools, environmental education centres, etc.). }\end{array}$ & $\begin{array}{l}\text { This action is a pre-requisite for the successful } \\
\text { completion of other objectives, but is not a quantifiable } \\
\text { metric in itself. While no indicator is proposed to monitor } \\
\text { this action, it is nevertheless important to periodically } \\
\text { take stock of its progress qualitatively. The extent of } \\
\text { non-formal and informal learning taking place at work } \\
\text { may be measured from the Adults in lifelong learning } \\
\text { indicator. }\end{array}$ & \\
\hline $\begin{array}{l}\text { 1204-develop and implement a quality assessment } \\
\text { framework for pre-school and general education and } \\
\text { develop a quality management framework for } \\
\text { continuing education. }\end{array}$ & $\begin{array}{l}\text { This action is a pre-requisite for the successful } \\
\text { completion of other objectives, but is not a quantifiable } \\
\text { metric in itself. While no indicator is proposed to monitor } \\
\text { this action, it is nevertheless important to periodically } \\
\text { take stock of its progress through qualitative } \\
\text { assessments. }\end{array}$ & \\
\hline $\begin{array}{l}\text { 1205-develop a comprehensive approach to } \\
\text { supporting learners with special educational needs, } \\
\text { including talented learners on a case-by-case basis. }\end{array}$ & $\begin{array}{l}\text { Education personnel practices and Effectiveness of } \\
\text { education personnel practices: (iii) students' special } \\
\text { education needs } \\
+ \\
\text { Completion/Drop-out rate (by special education need } \\
\text { breakdown). }\end{array}$ & $\begin{array}{l}\text { National, Local, } \\
\text { School }\end{array}$ \\
\hline $\begin{array}{l}\text { 1206-develop a comprehensive approach to } \\
\text { supporting learners with a migrant background on a } \\
\text { case-by-case basis. }\end{array}$ & $\begin{array}{l}\text { Education personnel practices and Effectiveness of } \\
\text { education personnel practices: (iii) teaching in a } \\
\text { multicultural/multilingual environment } \\
+ \\
\text { Completion /Drop-out rate (by language spoken at } \\
\text { home). }\end{array}$ & $\begin{array}{l}\text { National, Local, } \\
\text { School }\end{array}$ \\
\hline $\begin{array}{l}\text { 1207-review learners' own responsibility and the } \\
\text { conditions of free studies in vocational and higher } \\
\text { education as well as educational support } \\
\text { mechanisms, including by ensuring access to } \\
\text { vocational and higher education regardless of the } \\
\text { socio-economic situation of learners. }\end{array}$ & $\begin{array}{l}\text { Educational attainment (by level of education and } \\
\text { programme orientation, socio-economic status and } \\
\text { language spoken at home). } \\
\text { It would also be useful to look at current patterns among } \\
\text { students through the indicator on Enrolment rate in } \\
\text { upper-secondary education (by programme orientation) } \\
\text { and in tertiary education, by socio-economic status. }\end{array}$ & $\begin{array}{l}\text { National, Local, } \\
\text { School }\end{array}$ \\
\hline
\end{tabular}




\begin{tabular}{|c|c|c|}
\hline $\begin{array}{l}\text { 1208-reinforce entrepreneurship and career } \\
\text { education and continue the development of the } \\
\text { career services system, including a comprehensive } \\
\text { system to discover and develop individuals' } \\
\text { capabilities; develop learners' capacities to analyse } \\
\text { their knowledge and skills and to plan their } \\
\text { educational path and career (inter alia, through } \\
\text { digitisation of the educational path). }\end{array}$ & Self-directed learner & $\begin{array}{l}\text { National, Local, } \\
\text { School }\end{array}$ \\
\hline $\begin{array}{l}\text { 1209-improve collaboration between different parties } \\
\text { for the prevention of dropping out from education } \\
\text { and making note and supporting those who } \\
\text { discontinue their education; to develop additional } \\
\text { measures to prevent dropping out and to bring those } \\
\text { who have discontinued their education back to } \\
\text { formal education (including people with low } \\
\text { educational attainment). }\end{array}$ & $\begin{array}{l}\text { Completion/Drop-out rate: drop-out } \\
+ \\
\text { Teacher support }\end{array}$ & National/Local \\
\hline $\begin{array}{l}1210 \text {-improve conditions and opportunities for } \\
\text { continuous self-development of adults, including the } \\
\text { development and implementation of a combined } \\
\text { funding model that takes into account the } \\
\text { responsibilities of different parties. }\end{array}$ & Adults in lifelong learning & $\begin{array}{l}\text { National/Local } \\
\text { National, Local, } \\
\text { School }\end{array}$ \\
\hline $\begin{array}{l}\text { 1211-mandate the government to create } \\
\text { opportunities for low-skilled and low-educated adults } \\
\text { to develop learning habits and for self-development, } \\
\text { including digital inclusion. }\end{array}$ & $\begin{array}{l}\text { Adults in lifelong learning (by educational attainment } \\
\text { and region). }\end{array}$ & National/Local \\
\hline $\begin{array}{l}\text { 1212-ensure that local authorities guarantee the } \\
\text { availability of information and support for the } \\
\text { participation of adults in lifelong learning. }\end{array}$ & Adults in lifelong learning (by region). & National/Local \\
\hline
\end{tabular}

Action Trajectory 1.3. Promoting internationalisation and learning mobility in order to diversify learning opportunities, improve the quality of education and promote wider awareness of the Estonian language and culture.

Table 4. Indicators mapped to Action Trajectory 1.3

\begin{tabular}{l|l|l}
\hline Action & Indicator & $\begin{array}{l}\text { Recommended } \\
\text { monitoring level }\end{array}$ \\
\hline $\begin{array}{l}\text { 1301-develop additional measures to increase the } \\
\text { mobility of teachers, vocational teachers, support } \\
\text { specialists and university teaching staff, in particular } \\
\text { within the European Union. }\end{array}$ & $\begin{array}{l}\text { Education personnel practices: (iv) participating in } \\
\text { short-term mobility }\end{array}$ & $\begin{array}{l}\text { National, Local, } \\
\text { Schools }\end{array}$ \\
\hline $\begin{array}{l}\text { 1302-develop measures for greater inclusion of } \\
\text { international academic staff. }\end{array}$ & The percentage of international academic staff. & $\begin{array}{l}\text { National, Local, } \\
\text { Schools }\end{array}$ \\
\hline $\begin{array}{l}\text { 1303-create opportunities for increasing the } \\
\text { participation of Estonian school and university } \\
\text { students in learning mobility. }\end{array}$ & Short-term learning mobility & National, Local, \\
\hline $\begin{array}{l}\text { 1304-ensure the recognition of periods of learning } \\
\text { mobility at all levels of education by improving the } \\
\text { international comprehensibility and transparency of } \\
\text { certificates and diploma. }\end{array}$ & $\begin{array}{l}\text { This action is a pre-requisite for the successful } \\
\text { input to this indicator. } \\
\text { metric in itself. While no indicator is proposed to } \\
\text { monitor this action, it is nevertheless important to } \\
\text { periodically take stock of its progress qualitatively. }\end{array}$ & Schetences may provide \\
\hline $\begin{array}{l}\text { 1305-promote long-term international strategic } \\
\text { co-operation in policy making in the field of } \\
\text { education and training. }\end{array}$ & $\begin{array}{l}\text { This action is a pre-requisite for the successful } \\
\text { completion of other objectives, but is not a quantifiable } \\
\text { metric in itself. While no indicator is proposed to } \\
\text { monitor this action, it is nevertheless important to } \\
\text { periodically take stock of its progress qualitatively. }\end{array}$ & \\
\hline
\end{tabular}




\title{
26 | No. 47 - Enhancing data informed strategic governance in education in Estonia
}

\begin{tabular}{l|l|l}
\hline $\begin{array}{l}\text { 1306-provide foreign language learning and } \\
\text { education in foreign languages in order to support } \\
\text { internationalisation and learning mobility. }\end{array}$ & $\begin{array}{l}\text { The percentage of students learning a foreign } \\
\text { language within an educational institution, by level of } \\
\text { education. }\end{array}$ & $\begin{array}{l}\text { National, Local, } \\
\text { Schools }\end{array}$ \\
\hline 1307-improve the capacity of educational marketing. & $\begin{array}{l}\text { This action is a pre-requisite for the successful } \\
\text { completion of other objectives, but is not a quantifiable } \\
\text { metric in itself. While no indicator is proposed to } \\
\text { monitor this action, it is nevertheless important to } \\
\text { periodically take stock of its progress qualitatively. }\end{array}$ & \\
\hline
\end{tabular}

\section{Strategic Goal 2: In Estonia, there are competent and motivated teachers and school heads, a diverse learning environment and learner-centred education.}

\author{
Action Trajectory 2.1. The principles of contemporary approaches to learning and teaching \\ are implemented at all levels and in all types of education in order to ensure that the \\ process and content of learning support the development of self-directed learners, \\ empowers both learners and teachers and that time use is flexible. The implementation of \\ contemporary approaches to learning supports the acquisition of knowledge of various \\ disciplines, together with the skills of using the knowledge in practice, as well as the \\ development of learning, co-operation and self-direction skills. Resulting from better \\ physical and mental health, the subjective well-being improves.
}

Table 5. Indicators mapped to Action Trajectory 2.1

\begin{tabular}{|c|c|c|}
\hline Action & Indicator & $\begin{array}{l}\text { Recommended } \\
\text { monitoring level }\end{array}$ \\
\hline 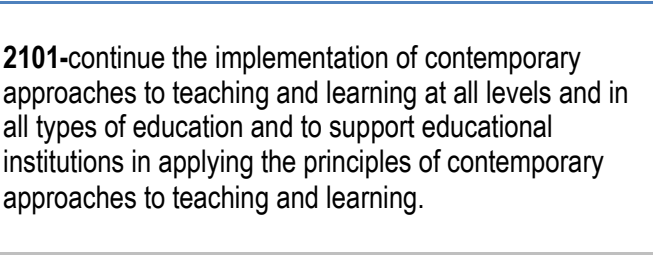 & $\begin{array}{l}\text { This action is a pre-requisite for the successful completion } \\
\text { of other objectives, in particular, the indicators on Student } \\
\text { performance, Self-directed learner, Collaborative } \\
\text { problem solving, but is not a quantifiable metric. While } \\
\text { no indicator is proposed to monitor this action, it is } \\
\text { nevertheless important to take periodically stock of its } \\
\text { progress through qualitative assessments. }\end{array}$ & \\
\hline $\begin{array}{l}\text { 2102-develop within the quality-control system a system } \\
\text { of monitoring the implementation of the contemporary } \\
\text { approach to learning and teaching. }\end{array}$ & $\begin{array}{l}\text { This action is a pre-requisite for the successful completion } \\
\text { of other objectives, in particular, the indicators on Student } \\
\text { performance, Self-directed learner, Collaborative } \\
\text { problem solving but is not a quantifiable metric. While no } \\
\text { indicator is proposed to monitor this action, it is } \\
\text { nevertheless important to take periodically stock of its } \\
\text { progress through qualitative assessments. }\end{array}$ & \\
\hline $\begin{array}{l}\text { 2103-increase learners' responsibility for their studies, } \\
\text { taking into account that attitudes and values are } \\
\text { normally developed at an early age, while creating } \\
\text { opportunities for learners to assume responsibility for } \\
\text { their studies in higher education and in lifelong learning. }\end{array}$ & Self-directed learner & $\begin{array}{l}\text { National, Local, } \\
\text { School }\end{array}$ \\
\hline $\begin{array}{l}\text { 2104-create a physically and mentally safe environment } \\
\text { that supports all parties involved in teaching and } \\
\text { learning. }\end{array}$ & $\begin{array}{l}\text { Subjective well-being of participants (learners and } \\
\text { teachers) } \\
\text { Teacher support } \\
\text { This action also provides input to the indicator on teacher } \\
\text { retention. }\end{array}$ & $\begin{array}{l}\text { National, Local, } \\
\text { School }\end{array}$ \\
\hline $\begin{array}{l}\text { 2105-provide support and opportunities for parents to } \\
\text { develop their role as a supportive and informed parent. }\end{array}$ & $\begin{array}{l}\text { This action is a pre-requisite for the successful completion } \\
\text { of other objectives, but is not a quantifiable metric in itself. } \\
\text { While no indicator is proposed to monitor this action, it is } \\
\text { nevertheless important to take periodically stock of its } \\
\text { progress qualitatively. }\end{array}$ & \\
\hline
\end{tabular}




\begin{abstract}
Action Trajectory 2.2. In order to increase the effectiveness of learning and to continuously support the development of learners, curriculum development and implementation as well as the assessment of learners is based on the principles of contemporary approaches to teaching and learning and the development of smart learning resources and methodology.
\end{abstract}

Table 6. Indicators mapped to Action Trajectory 2.2

\begin{tabular}{|c|c|c|}
\hline Action & Indicator & $\begin{array}{l}\text { Recommended } \\
\text { monitoring level }\end{array}$ \\
\hline $\begin{array}{l}\text { 2201-modernise the process and content of learning and } \\
\text { develop, in co-operation between the parties, science } \\
\text { and data-based curricula based on the principles of } \\
\text { sustainable development in order to devote increased } \\
\text { attention to the development of general competences, } \\
\text { including the development of self-directed learners and } \\
\text { citizens, in addition to providing subject-related } \\
\text { knowledge and skills. }\end{array}$ & $\begin{array}{l}\text { The development of general competences, self-directed } \\
\text { learners and citizens, and the provision of subject-related } \\
\text { knowledge and skills is provided through the following } \\
\text { indicators: } \\
\text { Student performance, Self-directed learner, } \\
\text { Collaborative problem solving } \\
\text { This modernisation of the process and content of } \\
\text { learning is a pre-requisite for the successful completion } \\
\text { of other objectives, but is not a quantifiable metric. While } \\
\text { no indicator is proposed to monitor this action, it is } \\
\text { nevertheless important to periodically take stock of its } \\
\text { progress through qualitative assessments. }\end{array}$ & $\begin{array}{l}\text { National, Local, } \\
\text { School }\end{array}$ \\
\hline $\begin{array}{l}\text { 2202-increase the use of practical learning (e.g. problem } \\
\text { solving and project-based learning) to make assignments } \\
\text { more meaningful for learners and to develop the capacity } \\
\text { to solve any issues related to personal life, learning, local } \\
\text { community and society in a creative, collaborative and } \\
\text { innovative way. }\end{array}$ & Collaborative problem solving & $\begin{array}{l}\text { National, Local, } \\
\text { School }\end{array}$ \\
\hline $\begin{array}{l}\text { 2203-provide all people with more exposure to the world } \\
\text { of labour and opportunities to participate in civil society } \\
\text { during their studies, by developing more practical } \\
\text { vocational and technology-related skills starting from } \\
\text { basic education and by creating opportunities for civic } \\
\text { participation, including through the integration of formal } \\
\text { and non-formal learning; promote the practical teaching } \\
\text { of Science, Technology, Engineering and Mathematics } \\
\text { (STEM) subjects in general education and to expand the } \\
\text { opportunities for integrated learning in Science, } \\
\text { Technology, Engineering, Arts and Mathematics } \\
\text { (STEAM) subjects in order to develop creativity, problem } \\
\text { solving and critical thinking in learners. }\end{array}$ & $\begin{array}{l}\text { Promoting the development of problem solving and } \\
\text { critical thinking is measured through the indicator } \\
\text { Collaborative problem solving and Global } \\
\text { Competencies. STEM subjects, in particular those } \\
\text { related to the acquisition of ICT skills are measured } \\
\text { through Digital competencies. } \\
\text { The development of practical vocational and } \\
\text { technology-related skills from basic education onwards } \\
\text { can be monitored by looking at the share of students } \\
\text { enrolled in formal programmes from upper-secondary to } \\
\text { tertiary education, and through participation in non-formal } \\
\text { and informal programmes. } \\
\text { The promotion of practical teaching of STEM subjects } \\
\text { and integrated learning in STEAM subjects requires } \\
\text { adjustments in curriculum and is a pre-requisite for the } \\
\text { development of creativity, problem solving and critical } \\
\text { thinking in learners. While no indicator is proposed to } \\
\text { monitor this action, it is nevertheless important to } \\
\text { periodically take stock of its progress through qualitative } \\
\text { assessments. }\end{array}$ & $\begin{array}{l}\text { National, Local, } \\
\text { School for } \\
\text { Collaborative } \\
\text { problem solving } \\
\text { skills. Digital } \\
\text { Competences is } \\
\text { only provided at } \\
\text { national level }\end{array}$ \\
\hline $\begin{array}{l}\text { 2204-change the assessment system so that it supports } \\
\text { the development of learners, including taking the } \\
\text { knowledge and skills acquired through non-formal and } \\
\text { informal learning into account in formal education; create } \\
\text { conditions and opportunities to make the development } \\
\text { and assessment of practical skills and general } \\
\text { competences a standard part of learning at all levels and } \\
\text { in all types of education. }\end{array}$ & $\begin{array}{l}\text { This action is a pre-requisite for the successful } \\
\text { completion of other objectives, but is not a quantifiable } \\
\text { metric in itself. While no indicator is proposed to monitor } \\
\text { this action, it is nevertheless important to periodically } \\
\text { take stock of its progress through qualitative } \\
\text { assessments. }\end{array}$ & \\
\hline
\end{tabular}




\section{No. 47 - Enhancing data informed strategic governance in education in Estonia}

2205-promote the development and implementation of diverse methods of learning and teaching (including digital pedagogy).

\author{
Education personnel practices: (iii) using ICT for \\ teaching \\ Effectiveness of education personnel practices: \\ (iii) using ICT for teaching \\ Education personnel practices: (iii) using ICT for \\ teaching \\ Effectiveness of education personnel practices: \\ (iii) using ICT for teaching \\ Digital competencies
}

2206-develop and use digital solutions as tools for educational innovation that enable the diversification and personalisation of education, including assessment for learning; raise awareness among participants in the learning process of the opportunities and risks of the information society; adopt a systematic approach to the introduction of new solutions.
Awareness of the opportunities and risks of the information society can be provided through the indicator on Self-directed learner. Capacity to distinguish between fact and opinion can be evaluated by the share of students attaining level 5 or 6 in the PISA literacy assessment from the Student Performance indicator (OECD, 2019[1]).

The systematic approach to the introduction of new solutions may be assessed through the Global Competencies.

Action Trajectory 2.3. Promoting the development of a shared space of culture and values, ensuring high-quality Estonian language instruction and learning of Estonian as well as promoting foreign language learning.

\section{Table 7. Indicators mapped to Action Trajectory 2.3}

\begin{tabular}{l|l|l}
\hline Action & Indicator & $\begin{array}{l}\text { Recommended } \\
\text { monitoring level }\end{array}$ \\
\hline $\begin{array}{l}\text { 2301-make teaching the Estonian language and culture a } \\
\text { national priority, by placing more value on learning } \\
\text { Estonian as a mother tongue. }\end{array}$ & $\begin{array}{l}\text { No indicator is proposed for this action given the } \\
\text { underlying concept of placing value on learning Estonian } \\
\text { as a mother tongue is not easily quantifiable. While no } \\
\text { indicator is proposed to monitor this action, it is } \\
\text { nevertheless important to periodically take stock of its } \\
\text { progress qualitatively. }\end{array}$ & Emergent literacy score from the OECD's International \\
\hline $\begin{array}{l}\text { 2302-increase the capacity to provide high-quality } \\
\text { instruction in Estonian in pre-school education. }\end{array}$ & $\begin{array}{l}\text { Early Learning and Child Well-Being Study (OECD, } \\
\text { 2020[21]). }\end{array}$ & National \\
\hline $\begin{array}{l}\text { 2303-ensure that students whose native or home } \\
\text { language is other than Estonian have a sufficient level of } \\
\text { linguistic competence for continuing their education and } \\
\text { succeeding in the labour market; provide additional or } \\
\text { compensatory Estonian language learning after basic } \\
\text { school, if necessary to increase proportion of students } \\
\text { who achieve level B2. }\end{array}$ & $\begin{array}{l}\text { Students performance: in literacy or Estonian as a } \\
\text { foreign language. }\end{array}$ & National, Local, \\
\hline $\begin{array}{l}\text { 2304-promote the development of a shared space of } \\
\text { culture and values in the course of the learning process } \\
\text { in order to increase the cohesiveness of society. }\end{array}$ & $\begin{array}{l}\text { This action is a pre-requisite for the successful } \\
\text { completion of other objectives, but is not a quantifiable } \\
\text { metric in itself. While no indicator is proposed to monitor } \\
\text { this action, it is nevertheless important to periodically } \\
\text { take stock of its progress qualitatively. }\end{array}$ & \\
\hline $\begin{array}{l}\text { 2305-promote the development of Estonian as a } \\
\text { language of higher education and research, including } \\
\text { developing and introducing Estonian terminology; } \\
\text { support the maintenance and development of } \\
\text { Estonian-language higher education curricula. }\end{array}$ & $\begin{array}{l}\text { This action is a pre-requisite for the successful } \\
\text { completion of other objectives, but is not a quantifiable } \\
\text { metric in itself. While no indicator is proposed to monitor } \\
\text { this action, it is nevertheless important to periodically } \\
\text { take stock of its progress qualitatively. }\end{array}$ & \\
\hline
\end{tabular}


2306-reinforce the learning of Estonian by international students and academic staff.

2307-develop and study the methodology of teaching Estonian as a second language; strengthen educators' willingness to work in a multilingual classroom.

2308-improve access to Estonian-language education and learning of Estonian by introducing digital solutions.
The share of international students enrolled in an educational institution where the language of instruction is Estonian.

The share of international academic staff teaching in an educational institutions where the language of instruction is Estonian.

Students' performance: in literacy or Estonian as a foreign language; Education personnel practices: (iii) teaching in a multicultural/multilingual environment; Effectiveness of education personnel practices: (iii) teaching in a multicultural/multilingual environment. This action is a pre-requisite for the successful completion of other objectives, but is not a quantifiable metric in itself. While no indicator is proposed to monitor this action, it is nevertheless important to periodically take stock of its progress qualitatively.

Action Trajectory 2.4. Ensuring that the next generation of qualified teachers, university lecturers and educators, and support specialists have flexible opportunities to enter the profession, as well as providing support for new teachers and professional development opportunities throughout teacher career.

\section{Table 8. Indicators mapped to Action Trajectory 2.4}

\begin{tabular}{|c|c|c|}
\hline Action & Indicator & $\begin{array}{l}\text { Recommended } \\
\text { monitoring level }\end{array}$ \\
\hline $\begin{array}{l}\text { 2401-consistently analyse and modernise the content of } \\
\text { the profession of teacher, vocational teacher, university } \\
\text { teacher and support specialist. }\end{array}$ & $\begin{array}{l}\text { No indicator is proposed for this action given the } \\
\text { underlying concept of shared culture and values is not } \\
\text { easily quantifiable and does not allow for effective } \\
\text { monitoring. While no indicator is proposed to monitor this } \\
\text { action, it is nevertheless important to periodically take } \\
\text { stock of its progress qualitatively. }\end{array}$ & \\
\hline $\begin{array}{l}\text { 2402-develop and implement a coherent research-based } \\
\text { model of initial and continuing training for teachers and } \\
\text { support specialists that takes into account professional } \\
\text { standards; promote the introduction of professional } \\
\text { standard-based career models established by institutions } \\
\text { or school managers. }\end{array}$ & Teacher support & $\begin{array}{l}\text { National, Local, } \\
\text { School }\end{array}$ \\
\hline $\begin{array}{l}\text { 2403-school owners should link career models and } \\
\text { professional development of teachers with their salaries } \\
\text { and continuing training opportunities. }\end{array}$ & Teacher salaries & National \\
\hline $\begin{array}{l}\text { 2404-improve co-operation between teachers, vocational } \\
\text { teachers, support specialists and academic staff, both } \\
\text { within and between educational institutions, as well as } \\
\text { their mobility into different types of educational } \\
\text { institutions in Estonia and abroad; promote short-term } \\
\text { work placements of academic staff, vocational teachers } \\
\text { and general education teachers in companies. }\end{array}$ & Teacher collaboration & $\begin{array}{l}\text { National, Local, } \\
\text { School }\end{array}$ \\
\hline $\begin{array}{l}\text { 2405-develop measures to increase the effectiveness of } \\
\text { doctoral studies. }\end{array}$ & Educational attainment & National, Local \\
\hline $\begin{array}{l}2406 \text {-continue promoting the teaching profession and } \\
\text { increasing its visibility. }\end{array}$ & $\begin{array}{l}\text { Teaching profession valued in society } \\
\text { Teacher retention }\end{array}$ & $\begin{array}{l}\text { National, Local, } \\
\text { School } \\
\text { National, Local }\end{array}$ \\
\hline
\end{tabular}




\section{0 | No. 47 - Enhancing data informed strategic governance in education in Estonia}

\begin{tabular}{|c|c|c|}
\hline $\begin{array}{l}2407-\text { create flexible opportunities to train as a teacher, } \\
\text { university lecturer or support specialist and/or to enter } \\
\text { the profession; include more people from outside the } \\
\text { education sector to introduce more practical skills and } \\
\text { work experiences to the learning process. }\end{array}$ & $\begin{array}{l}\text { This action is a pre-requisite for the successful } \\
\text { completion of other objectives, but is not a quantifiable } \\
\text { metric. While no indicator is proposed to monitor this } \\
\text { action, it is nevertheless important to periodically take } \\
\text { stock of its progress qualitatively. }\end{array}$ & \\
\hline $\begin{array}{l}\text { 2408-offer educators a safe and motivating work } \\
\text { environment and competitive pay that takes into account } \\
\text { the level of wages in other sectors. }\end{array}$ & $\begin{array}{l}\text { Teacher salaries }+ \\
\text { Subjective well-being of participants: teachers }\end{array}$ & $\begin{array}{l}\text { National, Local } \\
\text { National, Local, } \\
\text { School }\end{array}$ \\
\hline $\begin{array}{l}\text { 2409-ensure high-quality support services by } \\
\text { implementing both the occupational qualification system } \\
\text { and quality management for services, including reliable } \\
\text { and research-based assessment instruments, } \\
\text { methodology and methodical resources. }\end{array}$ & $\begin{array}{l}\text { This action is a pre-requisite for the successful } \\
\text { completion of other objectives, but is not a quantifiable } \\
\text { metric. While no indicator is proposed to monitor this } \\
\text { action, it is nevertheless important to periodically take } \\
\text { stock of its progress qualitatively. }\end{array}$ & \\
\hline $\begin{array}{l}\text { 2410-support the capacity of adult educators to develop } \\
\text { learners' general and social competences within their } \\
\text { field of study and to develop an assessment and } \\
\text { feedback environment for educators which helps to } \\
\text { improve and harmonise the quality of training and } \\
\text { encourages them to assume greater responsibility for the } \\
\text { quality of teaching and learning. }\end{array}$ & Teacher support & $\begin{array}{l}\text { National, Local, } \\
\text { School }\end{array}$ \\
\hline $\begin{array}{l}\text { 2411-continue the development of a central information } \\
\text { system for continuing training; introduce self-assessment } \\
\text { tools based on the competence models of teachers and } \\
\text { heads of schools; create self-assessment opportunities } \\
\text { for support specialists and adult educators to support } \\
\text { their professional development. }\end{array}$ & $\begin{array}{l}\text { This action is a pre-requisite for the successful } \\
\text { completion of other objectives, but is not a quantifiable } \\
\text { metric in itself. While no indicator is proposed to monitor } \\
\text { this action, it is nevertheless important to periodically } \\
\text { take stock of its progress qualitatively. }\end{array}$ & \\
\hline $\begin{array}{l}\text { 2412-diversify work placement opportunities for teachers, } \\
\text { academic staff and support specialists and ensure work } \\
\text { placement and support systems (including induction } \\
\text { year) for both new and experienced teachers as well as } \\
\text { for support specialists. }\end{array}$ & $\begin{array}{l}\text { This action is a pre-requisite for the successful } \\
\text { completion of other objectives, but is not a quantifiable } \\
\text { metric in itself. While no indicator is proposed to monitor } \\
\text { this action, it is nevertheless important to periodically } \\
\text { take stock of its progress qualitatively. }\end{array}$ & \\
\hline
\end{tabular}

Action Trajectory 2.5. Ensuring a new generation of heads of schools, supporting their professional development, and developing and implementing an assessment system for heads of schools in order to promote educational innovation and create a safe learning environment that supports the physical and mental well-being of all.

Table 9. Indicators mapped to Action Trajectory 2.5

\begin{tabular}{l|l|l}
\hline Actions & Indicators & $\begin{array}{l}\text { Recommended } \\
\text { monitoring level }\end{array}$ \\
\hline $\begin{array}{l}\text { 2501-create career opportunities for individuals with high } \\
\text { management and leadership potential working in the } \\
\text { education sector; promote the profession outside the } \\
\text { education sector. }\end{array}$ & $\begin{array}{l}\text { This action is a pre-requisite for the successful } \\
\text { completion of other objectives, but is not a quantifiable } \\
\text { metric in itself. While no indicator is proposed to monitor } \\
\text { this action, it is nevertheless important to periodically } \\
\text { take stock of its progress qualitatively. }\end{array}$ & $\begin{array}{l}\text { Educational personnel practices, school heads } \\
\text { Teacher collaboration }\end{array}$ \\
$\begin{array}{l}\text { 2502-ensure that the recruitment of heads of schools, } \\
\text { support for their professional development and that } \\
\text { feedback delivery on their performance be based on the } \\
\text { competence model of the heads of schools. }\end{array}$ & $\begin{array}{l}\text { No indicator is proposed to address whether the } \\
\text { feedback delivery is based on the competence model of } \\
\text { school heads as this is not easily quantifiable. It is } \\
\text { nevertheless important to periodically take stock of its } \\
\text { progress qualitatively. }\end{array}$ & $\begin{array}{l}\text { National, Local, } \\
\text { School }\end{array}$ \\
\hline
\end{tabular}




\begin{tabular}{l|l|l}
\hline $\begin{array}{l}\text { 2503-enhance the capacity of school managers to recruit } \\
\text { heads of schools, support their professional development } \\
\text { and monitor and assess their performance. }\end{array}$ & $\begin{array}{l}\text { Educational personnel practices, school heads } \\
\text { The capacity of school managers to recruit heads of } \\
\text { schools could be measured by the average number of } \\
\text { qualified applicants for each open position. }\end{array}$ & $\begin{array}{l}\text { National, Local, } \\
\text { School }\end{array}$ \\
\hline $\begin{array}{l}\mathbf{2 5 0 4 - o f f e r ~ h i g h - q u a l i t y ~ a n d ~ e f f e c t i v e ~ c o n t i n u i n g ~ t r a i n i n g ~ a t ~} \\
\text { the beginner, intermediate and advanced levels in order } \\
\text { to support professional development of heads of schools } \\
\text { throughout their career and to ensure that their } \\
\text { competences are up to date. }\end{array}$ & $\begin{array}{l}\text { Educational personnel practices, school heads } \\
\text { Effectiveness of Educational personnel practices, } \\
\text { school heads }\end{array}$ & National, Local, \\
\hline $\begin{array}{l}\mathbf{2 5 0 5} \text {-promote co-operation between heads of schools to } \\
\text { share best evidence-based practices and use the } \\
\text { resources more efficiently. }\end{array}$ & Educational personnel practices, school heads & National, Local, \\
\hline
\end{tabular}

\title{
Strategic Goal 3: Learning options are responsive to the development needs of society and the labour market
}

\author{
Action Trajectory 3.1. Developing and implementing a sustainable system of forecasting \\ and monitoring skills needs which takes into account the needs of all target groups and of \\ co-ordinating actions between different actors in order to promote the acquisition of \\ knowledge and abilities that serve the labour market and to better link education to the \\ labour market.
}

Table 10. Indicators mapped to Action Trajectory 3.1

\begin{tabular}{|c|c|c|}
\hline Action & Indicator & $\begin{array}{l}\text { Recommended } \\
\text { monitoring level }\end{array}$ \\
\hline $\begin{array}{l}3101 \text {-agree on clear roles and responsibilities of social } \\
\text { partners that enable them to actively and meaningfully } \\
\text { participate in linking education to labour market needs. }\end{array}$ & $\begin{array}{l}\text { This action is a pre-requisite for the successful } \\
\text { completion of other objectives, but is not a quantifiable } \\
\text { metric in itself. While no indicator is proposed to monitor } \\
\text { this action, it is nevertheless important to periodically } \\
\text { take stock of its progress qualitatively. }\end{array}$ & \\
\hline $\begin{array}{l}\text { 3102-develop further and implement the needed skills, } \\
\text { monitoring, forecasting and feedback system; to improve } \\
\text { the capacity and update the method of analysing big data } \\
\text { in order to make it possible to forecast the need for skills } \\
\text { in particular, as opposed to the need for professions and } \\
\text { to make the results more widely usable. }\end{array}$ & $\begin{array}{l}\text { No indicator is proposed to monitor this action as the } \\
\text { concepts underlying it, such as capacity development, } \\
\text { are too broad for effective monitoring. However, the } \\
\text { indicator on Employed recent graduates is important to } \\
\text { assess the labour market value of students following } \\
\text { graduation. }\end{array}$ & \\
\hline $\begin{array}{l}\text { 3103-carry out the reform of the occupational } \\
\text { qualification system, including shifting from occupational } \\
\text { standards to profiles, developing a skills matrix and } \\
\text { classification system, criteria and tools for assessing } \\
\text { skills for different target groups, and recognition of } \\
\text { general and professional competences and partial } \\
\text { qualifications. }\end{array}$ & $\begin{array}{l}\text { This action is a pre-requisite for the successful } \\
\text { completion of other objectives, but is not a quantifiable } \\
\text { metric in itself. While no indicator is proposed to monitor } \\
\text { this action, it is nevertheless important to periodically } \\
\text { take stock of its progress qualitatively. }\end{array}$ & \\
\hline $\begin{array}{l}\text { 3104-develop a digital solution for the management of } \\
\text { individual educational paths and careers and assessment } \\
\text { of skills (digital education history). }\end{array}$ & $\begin{array}{l}\text { This action is a pre-requisite for the successful } \\
\text { completion of other objectives, but is not a quantifiable } \\
\text { metric in itself. While no indicator is proposed to monitor } \\
\text { this action, it is nevertheless important to periodically } \\
\text { take stock of its progress qualitatively. }\end{array}$ & \\
\hline $\begin{array}{l}\text { 3105-develop vocational certification based the principles } \\
\text { agreed upon within Estonia and internationally. }\end{array}$ & $\begin{array}{l}\text { This action is a pre-requisite for the successful } \\
\text { completion of other objectives, but is not a quantifiable } \\
\text { metric in itself. While no indicator is proposed to monitor } \\
\text { this action, it is nevertheless important to periodically } \\
\text { take stock of its progress qualitatively. }\end{array}$ & \\
\hline
\end{tabular}




\section{No. 47 - Enhancing data informed strategic governance in education in Estonia}

\begin{tabular}{l|l|l}
\hline 3106-ensure the implementation and interoperability of & This action is a pre-requisite for the successful \\
instruments for comparison and recognition of EU & completion of other objectives, but is not a quantifiable \\
qualifications and prior learning and work experiences by & metric in itself. While no indicator is proposed to monitor \\
promoting exchange of experiences with other Member & this action, it is nevertheless important to periodically \\
$\begin{array}{l}\text { States and prioritising the development of mechanisms } \\
\text { for recognising prior learning and work experience. }\end{array}$ & take stock of its progress qualitatively. \\
\hline
\end{tabular}

Action Trajectory 3.2. Supporting the development of competences that create more added value; improving continuing training and retraining opportunities, including work-based learning, to respond swiftly to the development needs of the labour market and ensure that people are equipped with the right knowledge and skills for employment.

\section{Table 11. Indicators mapped to Action Trajectory 3.2}

\begin{tabular}{|c|c|c|}
\hline Action & Indicator & $\begin{array}{l}\text { Recommended } \\
\text { monitoring level }\end{array}$ \\
\hline $\begin{array}{l}3201 \text {-enhance the capacity of providers of continuing } \\
\text { training and retraining to respond swiftly to the } \\
\text { developments of the labour market and the economic } \\
\text { environment, including growth areas of smart } \\
\text { specialisation and areas that need to be prioritised }\end{array}$ & $\begin{array}{l}\text { Employed recent graduates: disaggregated by specific } \\
\text { fields of study } \\
\text { Employed graduates in growth areas of smart } \\
\text { specialisation. } \\
\text { Share of students enrolled in growth areas of smart } \\
\text { specialisation and priority areas }\end{array}$ & National, Local \\
\hline $\begin{array}{l}\text { 3202-provide more vocational and higher education as } \\
\text { well as continuing training and retraining opportunities in } \\
\text { the areas that need to be prioritised and for jobs that } \\
\text { bring more added value }\end{array}$ & $\begin{array}{l}\text { Educational attainment } \\
\text { Adults in lifelong learning }\end{array}$ & National, Local \\
\hline $\begin{array}{l}\text { 3203-strengthen the role of vocational and higher } \\
\text { education in the provision of high-quality continuing } \\
\text { training, including curriculum development, training of } \\
\text { trainers, etc. }\end{array}$ & $\begin{array}{l}\text { This action is a pre-requisite for the successful } \\
\text { completion of other objectives, but is not a quantifiable } \\
\text { metric in itself. While no indicator is proposed to monitor } \\
\text { this action, it is nevertheless important to periodically } \\
\text { take stock of its progress qualitatively. }\end{array}$ & \\
\hline $\begin{array}{l}\text { 3204-support career change opportunities by determining } \\
\text { training needs and implementing support measures. }\end{array}$ & $\begin{array}{l}\text { This action is a pre-requisite for the successful } \\
\text { completion of other objectives, but is not a quantifiable } \\
\text { metric in itself. While no indicator is proposed to monitor } \\
\text { this action, it is nevertheless important to periodically } \\
\text { take stock of its progress qualitatively. }\end{array}$ & \\
\hline $\begin{array}{l}\text { 3205-promote continuous self-development and } \\
\text { participation in learning by paying more attention to the } \\
\text { target groups not in education or training }\end{array}$ & $\begin{array}{l}\text { Adults in lifelong learning, by prior educational } \\
\text { attainment }\end{array}$ & National, Local \\
\hline $\begin{array}{l}\text { 3206-promote more efficient exploitation of the } \\
\text { employment potential of the adult population by providing } \\
\text { continuing training and flexible learning opportunities, } \\
\text { including opportunities to start a business and combine } \\
\text { studies and work }\end{array}$ & Adults in lifelong learning, by labour status & National, Local \\
\hline 3207-promote STEM fields. & $\begin{array}{l}\text { Share of upper-secondary Vocational Education and } \\
\text { Training (VET) or tertiary students enrolled in a STEM } \\
\text { field of study. } \\
\text { Career expectations of 15-year-olds as reported in PISA }\end{array}$ & National \\
\hline $\begin{array}{l}\text { 3208-raise awareness of the opportunities and risks of } \\
\text { the information society and develop digital skills in all age } \\
\text { groups for the purpose of digital involvement. }\end{array}$ & $\begin{array}{l}\text { Digital competencies } \\
\text { Awareness of the opportunities and risks of the } \\
\text { information society can be provided through the indicator } \\
\text { on Self-directed learner. Capacity to distinguish } \\
\text { between fact and opinion can be evaluated by the share } \\
\text { of students attaining level } 5 \text { or } 6 \text { in the PISA literacy } \\
\text { assessment from the Student Performance indicator } \\
\left(O E C D, 2019_{[1]}\right) \text {. }\end{array}$ & National \\
\hline
\end{tabular}


3209-develop entrepreneurship skills at all levels and in all types of education.

Entrepreneurial competencies are defined as knowledge skills and attitudes that affect the willingness and ability to perform the entrepreneurial job of new value creation (Martin Lackéus, 2015[18]). Therefore, entrepreneurial capacity can be measured through a combination of indicators, such as educational attainment in certain fields of study (knowledge), Collaborative problem solving or creativity (skills), Global competencies or capacity to develop a growth mindset (attitude) (Gouëdard, 2021 [19]; OECD, $2021_{[20]}$ ), among others. Share of students enrolled in growth areas of smart specialisation and benefiting from financial support mechanisms.

study loan, etc., including for studying abroad) to promote professions that are not attractive for learners but are highly required and create more added value in society.

Share of students enrolled in growth areas of smart specialisation and priority areas, by level of education.

This action is a pre-requisite for the successful completion of other objectives, but is not a quantifiable metric in itself. While no indicator is proposed to monitor this action, it is nevertheless important to periodically take stock of its progress qualitatively. inter alia, to keep talent in Estonia and attract new talent to Estonia and integrate them into our society.

3212-promote the inclusion of international school and university students in Estonian society as well as the transition of graduates to the labour market; to improve support measures (including learning Estonian beyond level A2) to ensure that international students and graduates stay in Estonia.

3213-increase openness to innovation and improve national and international co-operation between educational institutions and the labour market in relation to innovative development activities; promote, through education and R\&D, the participation of companies in global value chains, including developing and introducing state-of-the-art technologies; develop industrial doctoral and Master's studies.

3214-continue the development and expansion of the work-based learning and work placement system (quality, broadening the scope of learning mobility, promotion), based on the needs of society and the world of labour.

Share of international students studying in Estonia (degree or credit mobility).

Employed recent graduates, breakdown by national/international students.

This action is a pre-requisite for the successful completion of other objectives, but is not a quantifiable metric in itself. While no indicator is proposed to monitor this action, it is nevertheless important to periodically take stock of its progress qualitatively.

Work experience when studying
National.

National, local, school.

National, Local, School

National, Local

\section{Summary of the proposed set of indicators}

Table 12 summarises the indicators proposed at national/regional and at school level to monitor the Estonia Education Strategy. A number of the indicators are adapted from Estonia's own selection of general objectives and strategic goals indicators, while others have been newly identified to fill in monitoring gaps of the strategy, for a total of 22 indicators. The indicators are grouped according to whether they measure an input into one of the three goals of the Estonian Education Strategy, a process, or the learning, labour market, and social outcomes of the education system. The table also summarises the monitoring level for each of the indicators. This depends on the actionability, or level of control that various stakeholders have at each of these levels to act on the results and implement corrective or preventive actions. While indicators relevant for schools can all be aggregated up at local or national level, the opposite is not true and depends on the perimeter of autonomy that schools are attributed. Out of the 22 total indicators proposed for monitoring at national or local level, 14 of them are proposed to track education progress at school level. Finally, the table also presents a concise overview of the data gaps that would need to be bridged in order to implement the indicator proposal. 


\section{No. 47 - Enhancing data informed strategic governance in education in Estonia}

Table 12. Summary of indicators proposed at national, local and at school level

\begin{tabular}{|c|c|c|c|c|c|}
\hline & Indicator & OG/SG & $\begin{array}{l}\text { National/ } \\
\text { local } \\
\text { level }\end{array}$ & $\begin{array}{l}\text { School } \\
\text { level }\end{array}$ & $\begin{array}{l}\text { Data gaps between existing and recommended } \\
\text { indicators }\end{array}$ \\
\hline \multirow{4}{*}{ Input } & Expenditure in education & & $X$ & & \\
\hline & $\begin{array}{l}\text { Teaching profession valued } \\
\text { in society }\end{array}$ & & $X$ & $X$ & \multirow{2}{*}{$\begin{array}{l}\text { Data collected at national level every } 5 \text { years through TALIS - } \\
\text { would need to be included in regular national surveys to have } \\
\text { data at school level and annually }\end{array}$} \\
\hline & Teacher collaboration & & $X$ & $X$ & \\
\hline & Teacher salaries & GO 7 & $x$ & & Comparison with the salary of similarly educated workers. \\
\hline \multirow{7}{*}{ Process } & Teacher support & & $X$ & $X$ & $\begin{array}{l}\text { Data collected at national level through PISA - would need to } \\
\text { be included in annual national survey to have data at school } \\
\text { level and annually. }\end{array}$ \\
\hline & Pre-schooling & SG 1.3 & $X$ & & Include enrolment from age 3 until entry to primary school. \\
\hline & Completion / drop-out rate & $\begin{array}{c}1.2 .1 / \\
1.2 .2\end{array}$ & $X$ & $X$ & Capture completion and repetition in addition to drop-out rate. \\
\hline & Short-term learning mobility & SG 1.4 & $x$ & $\mathrm{X}$ & \\
\hline & $\begin{array}{l}\text { Education personnel } \\
\text { practices }\end{array}$ & & $X$ & $X$ & $\begin{array}{l}\text { Data collected at national level through TALIS - would need to } \\
\text { be included in regular national survey to have data at school } \\
\text { level and annually. }\end{array}$ \\
\hline & $\begin{array}{l}\text { Work experience when } \\
\text { studying }\end{array}$ & & $X$ & $X$ & $\begin{array}{l}\text { Eurostat data, last data from } 2016 \text { and next in } 2024 \text {. Eurostat } \\
\text { is currently testing the inclusion of new variables in the annual } \\
\text { Labour Force Survey (LFS) survey of work experience at a } \\
\text { work place, which would allow more frequent measurement of } \\
\text { this indicator. }\end{array}$ \\
\hline & Adults in lifelong learning & GO 3 & $X$ & & \\
\hline \multirow{11}{*}{ Output/Outcome } & $\begin{array}{l}\text { Subjective well-being of } \\
\text { participants }\end{array}$ & SG 2.3 & $X$ & $X$ & $\begin{array}{l}\text { Other dimensions of well-being such as physical well-being } \\
\text { should also be added. Monitor every year (instead of every } \\
\text { three years) for teachers. }\end{array}$ \\
\hline & Educational attainment & $\begin{array}{l}\text { SG } \\
1.1 / 1.2 \\
\& \mathrm{GO} 1\end{array}$ & $X$ & & \\
\hline & Student performance & $\begin{array}{l}\text { SG } \\
2.1 / 2.4 \\
\text { GO } 6\end{array}$ & $X$ & $X$ & $\begin{array}{c}\text { Current data available is from PISA, monitored every three } \\
\text { years at national level only. To monitor this indicator at other } \\
\text { ages, at school level, and more regularly, it is recommended to } \\
\text { use the national tests (for grades } 3 \text { and } 6 \text { ). Investigate the } \\
\text { inclusion of a broad range of competences, such as literacy, } \\
\text { sciences, mathematics, ICT (SG2.2 \& 2.3.1), or Estonian as a } \\
\text { foreign language (2.2.4). }\end{array}$ \\
\hline & $\begin{array}{l}\text { Collaborative problem solving } \\
\text { skills }\end{array}$ & & $X$ & $X$ & $\begin{array}{c}\text { From PISA 2015, not collected on a regular cycle. Questions } \\
\text { may be integrated in national assessments for timelier } \\
\text { measurements. }\end{array}$ \\
\hline & Self-directed learner & GO 5 & $x$ & $\mathrm{X}$ & \\
\hline & Global competencies & & $X$ & $X$ & $\begin{array}{c}\text { From PISA 2018, not collected on a regular cycle. Questions } \\
\text { may be integrated in national assessments for timelier } \\
\text { measurements. }\end{array}$ \\
\hline & $\begin{array}{l}\text { Effectiveness of education } \\
\text { personnel practices }\end{array}$ & & $X$ & $X$ & $\begin{array}{l}\text { Data collected at national level through TALIS - would need to } \\
\text { be included in annual national satisfaction survey to have data } \\
\text { at school level and annually. }\end{array}$ \\
\hline & Teacher retention & SG 2.5 & $x$ & & \\
\hline & Digital competencies & SG 3.2 & $X$ & $X$ & \\
\hline & Employed recent graduates & SG 3.1 & $x$ & & \\
\hline & $\begin{array}{l}\text { Employment in growth areas } \\
\text { of SMARTart specialisation }\end{array}$ & GO 4 & $X$ & & \\
\hline
\end{tabular}




\section{References}

Estonian Ministry of Education and Research (2019), Estonian Education and Research Strategy 2021-2035: Smart and Active Estonia 2035,

https://www.hm.ee/sites/default/files/tark ja tegus eng a43mm.pdf (accessed on 27 September 2021).

Gouëdard, P. (2021), "Can a growth mindset help disadvantaged students close the gap?", PISA in Focus, No. 112, OECD Publishing, Paris, https://dx.doi.org/10.1787/20922f0d-en.

Gouëdard, P. (2021), "Developing indicators to support the implementation of education policies", OECD Education Working Papers, No. 255, OECD Publishing, Paris, https://dx.doi.org/10.1787/b9f04dd0-en.

Martin Lackéus (2015), Entrepreneurship in Education: what, why, when how, https://www.oecd.org/cfe/leed/BGP Entrepreneurship-in-Education.pdf (accessed on 25 April 2019).

OECD (2021), Proposal for a coherent set of indicators and guidelines for education monitoring, https://www.hm.ee/sites/default/files/hariduskava 2035 moodikud oecd ettepanek indicator selection tolge03.05.2021.xlsx (accessed on 27 September 2021).

OECD (2021), Sky's the limit: Growth mindset, students, and schools in PISA, OECD Publishing, Paris, https://www.oecd.org/pisa/growth-mindset.pdf.

OECD (2020), "An implementation framework for effective change in schools", OECD Education Policy Perspectives, No. 9, OECD Publishing, Paris, https://dx.doi.org/10.1787/4fd4113f-en.

OECD (2020), Analytical tools for education strategy mapping and their technical note for future uses by the MoER.

OECD (2020), Capacity-building workshop on monitoring Estonia's Education Strategy 2035.

OECD (2020), Draft proposal for a comprehensive set of indicators and principles for education monitoring.

OECD (2020), Early Learning and Child Well-being: A Study of Five-year-Olds in England, Estonia, and the United States, OECD Publishing, Paris, https://dx.doi.org/10.1787/3990407fen.

OECD (2020), Education Policy Outlook: Estonia, https://www.oecd.org/education/policyoutlook/country-profile-Estonia-2020.pdf.

OECD (2020), Note summarising current monitoring processes, data and indicator frameworks in Estonia in a comparative perspective, https://www.hm.ee/sites/default/files/1.1. eesti hariduse seire ia hindamissusteemi vordlev analuus eng .pdf (accessed on 27 September 2021).

OECD (2020), TALIS 2018 Results (Volume II): Teachers and School Leaders as Valued Professionals, TALIS, OECD Publishing, Paris, https://dx.doi.org/10.1787/19cf08df-en.

OECD (2019), OECD Reviews of Evaluation and Assessment in Education: North Macedonia, OECD Reviews of Evaluation and Assessment in Education, OECD Publishing, Paris, https://dx.doi.org/10.1787/079fe34c-en. 
36 | No. 47 - Enhancing data informed strategic governance in education in Estonia

OECD (2019), PISA 2018 Results (Volume I): What Students Know and Can Do, PISA, OECD Publishing, Paris, https://dx.doi.org/10.1787/5f07c754-en.

OECD (2019), PISA 2018 Results (Volume II): Where All Students Can Succeed, PISA, OECD Publishing, Paris, https://dx.doi.org/10.1787/b5fd1b8f-en.

OECD (2013), Synergies for Better Learning: An International Perspective on Evaluation and Assessment, OECD Reviews of Evaluation and Assessment in Education, OECD Publishing, Paris, https://dx.doi.org/10.1787/9789264190658-en.

Santiago, P. et al. (2016), OECD Reviews of School Resources: Estonia 2016, OECD Reviews of School Resources, OECD Publishing, Paris, https://dx.doi.org/10.1787/9789264251731-en.

Tammets, K. et al. (2021), Report on current data use and future data needs of schools and school owners in Estonia, https://www.hm.ee/sites/default/files/output 1.3.2 report on current data use and future da ta needs of schools and school owners final.pdf (accessed on 27 September 2021).

Viennet, R. and B. Pont (2017), "Education policy implementation: A literature review and proposed framework", OECD Education Working Papers, No. 162, OECD Publishing, Paris, https://dx.doi.org/10.1787/fc467a64-en. 


\section{Annex A. Summary of project outputs}

\section{Table 13. OECD outputs delivered for the project}

\begin{tabular}{|c|c|}
\hline $\begin{array}{c}\text { Output } \\
1.1\end{array}$ & $\begin{array}{l}\text { Note summarising current monitoring processes, data and indicator frameworks in Estonia in a } \\
\text { comparative perspective } \\
\text { This note analyses Estonia's current monitoring processes, data and indicator frameworks in comparison with } \\
\text { two countries. }\end{array}$ \\
\hline $\begin{array}{c}\text { Output } \\
1.2\end{array}$ & $\begin{array}{l}\text { Note with analytical framework to support the mapping of national data sources and indicators } \\
\text { This note presents a framework to support the mapping of national data sources and indicators in Estonia (Input / } \\
\text { Process / Outputs / Outcomes). }\end{array}$ \\
\hline $\begin{array}{c}\text { Output } \\
1.3 .1\end{array}$ & $\begin{array}{l}\text { Analytical tools for education strategy mapping and their technical note for future uses by the MoER } \\
\text { Tool A: Linking goals and outcomes in a strategy } \\
\text { Tool B: Linking key indicators, goal indicators and outcomes in a strategy } \\
\text { Tool C: Mapping strategic goals' indicators according to the Input / Process / Output / Outcome framework } \\
\text { Tool D: Linking suggested indicators and data to help monitor progress with a strategy. }\end{array}$ \\
\hline $\begin{array}{c}\text { Output } \\
1.3 .2\end{array}$ & $\begin{array}{l}\text { Report on current data use and future data needs of schools and school owners in Estonia } \\
\text { This report describes the use of educational data by school owners, school leaders and teachers, identifies their } \\
\text { data needs, and studies the factors affecting schools' readiness to use different types of data in school } \\
\text { improvement. }\end{array}$ \\
\hline $\begin{array}{c}\text { Output } \\
1.4\end{array}$ & $\begin{array}{l}\text { Stakeholder seminar on monitoring and evaluation practices and its Summary note } \\
\text { The stakeholder event was held online on } 27 \text { May 2020, to consult stakeholders about Estonia's education } \\
\text { monitoring and evaluation practices, and data needs. The note summarises feedback and recommendations } \\
\text { made by stakeholders at the event. }\end{array}$ \\
\hline $\begin{array}{c}\text { Output } \\
2.1\end{array}$ & $\begin{array}{l}\text { Draft proposal for a comprehensive set of indicators and principles for education monitoring } \\
\text { This note systematically reviews existing indicators initially proposed in Estonia for its draft Education Strategy } \\
\text { and a set of initial recommendations for effective education monitoring. This note contributed to developing } \\
\text { Output 2.4. }\end{array}$ \\
\hline $\begin{array}{c}\text { Output } \\
2.2\end{array}$ & $\begin{array}{l}\text { Capacity-building workshop on monitoring Estonia's Education Strategy } 2035 \text { and Outputs from group } \\
\text { activities } \\
\text { The workshop was held online on } 10 \text { December to help MoER officials and selected stakeholders develop their } \\
\text { capacity in strategic indicator selection and monitoring. Presentations and outputs summarising group work were } \\
\text { provided. }\end{array}$ \\
\hline $\begin{array}{c}\text { Output } \\
2.3\end{array}$ & $\begin{array}{l}\text { Final stakeholder webinar } \\
\text { This final webinar was held online on } 29 \text { April } 2021 \text { to present the final set of indicators to education stakeholders } \\
\text { (Output 2.4), receive feedback from stakeholders on the use of these indicators at school level, and discuss the } \\
\text { use of these indicators in relation to the strategy in the future }\end{array}$ \\
\hline $\begin{array}{c}\text { Output } \\
2.4\end{array}$ & $\begin{array}{l}\text { Proposal for a coherent set of indicators and guidelines for education monitoring } \\
\text { This final note presents a proposal for a coherent set of indicators and guidelines for education monitoring that } \\
\text { align to Estonia's Education Strategy } 2035 \text {. }\end{array}$ \\
\hline
\end{tabular}

Source: The different Outputs of the project are available on the MoER website: https://www.hm.ee/et/hariduse_seire_ja_moodikud. 
38 No. 47 - Enhancing data informed strategic governance in education in Estonia

\section{Annex B. Composition of the Advisory Group}

Table 14. Teams from the MoER, the European Commission, and the OECD working on the project

\begin{tabular}{l|l|l}
\hline \multicolumn{1}{c|}{ MoER, Estonia } & \multicolumn{1}{|c}{$\begin{array}{c}\text { European Commission } \\
\text { (DG REFORM) }\end{array}$} & \multicolumn{1}{c}{ OECD } \\
\hline Tiina Annus & Lukas Demoen & Manon Costinot \\
\hline Tatjana Kiilo & Patricia Perez-Gomez & Pierre Gouëdard \\
\hline Maie Kitsing & Thomas Pritzkow & Corinne Heckman \\
\hline Kersti Kõiv & Konstantin Scheller & Camila de Moraes \\
\hline Marianne Leppik & & Beatriz Pont \\
\hline Rena Selliov & & Romane Viennet \\
\hline Elo Tuppits & & \\
\hline
\end{tabular}




\title{
Annex C. OECD team members
}

\begin{abstract}
Manon Costinot is a statistician at the OECD Directorate for Education and Skills. She produces indicators and analyses for the yearly publication of Education at a Glance. As one of the OECD representatives at the Technical Co-operation Group on SDG 4, she also contributes to the co-ordinated international effort to monitor progress on the 2030 agenda for sustainable development.

In addition, Manon has provided tailored technical guidance to countries/international organisations for the monitoring of education policies, notably the Asia-Pacific Economic Cooperation (APEC) 2030 education strategy. She also worked on the OECD Future of Education and Skills 2030 project, where she produced analyses on challenges and government initiatives to prepare youth for the future. Previously, she worked on policy evaluation in the fields of gender equity in access to employment and social protection, international development and health policy at UNECLAC, UNCTAD, Yale and MIT.
\end{abstract}

Manon holds a Master's in Economics and Public Policy from Sciences Po Paris.

Pierre Gouëdard is an analyst at the OECD Directorate for Education and Skills. An economist specialising in economics of education, he has conducted research in the areas of teacher careers, teacher health, affirmative action and access to higher education, and taught in the field of economics in Sciences Po and La Sorbonne.

At the OECD, Pierre has led the Japan Country Review, and the Norwegian and Estonian Implementation Support projects. He has also been part of the Greek Country Review, the Latvian Skills Review, and the Welsh initiative to transform Schools as Learning Organisations. He is currently leading the support to improve local community engagement in Ireland.

Pierre holds a PhD in Economic Sciences from Sciences Po Paris.

Corinne Heckmann is an analyst at the OECD Directorate for Education and Skills in the Division of Innovation and Measuring Progress. From 2005 to 2016, she was co-ordinator of the publication Education at a Glance: OECD indicators. Since 2017, in addition to her leading role in developing Education at a Glance (EAG) indicators, she also took on the responsibility of co-ordinating the Directorate's activities in relation to the technical implementation of the United Nations Sustainable Development Goals. She regularly intervenes in the media or at conferences to discuss the state of education in France and other OECD countries within an international context. Recently, she facilitated an APEC-OECD Education Data Workshop where she gave several presentations on how to create and monitor education indicators in light of the APEC Education Strategy. She also participated in the production of the blueprint to support the development of the technical metadata manual for the indicators.

Corinne holds a Master's degree in Econometric from the University Paris-X.

Camila de Moraes was a consultant at the OECD Directorate for Education and Skills until Spring 2020 and during the first phase of the project. She now works as a project officer at the United Nations Educational, Scientific and Cultural Organization (UNESCO) for the Global Education Monitoring Report.

At the OECD, Camila worked in the team responsible for the flagship publication Education at a Glance: OECD indicators and is responsible for developing indicators related to financial returns to education, to factors that influence education expenditure, to completion rates and to equity in education. She also contributes to the integration of the Sustainable Development Goal 4 (SDG 4) agenda in the OECD's 
40 | No. 47 - Enhancing data informed strategic governance in education in Estonia

Directorate for Education and Skills and is one of the OECD representatives in the technical groups responsible for developing the SDG 4 indicators.

Camila holds a Master's degree in Economics and Public Policy from Sciences Po Paris.

Beatriz Pont is a senior education policy analyst at the OECD Directorate for Education and Skills, with extensive experience in education policy reform internationally. She currently leads OECD's Implementing Education Policies project. She has specialised in various areas of education policy and reform, including equity and quality in education, school leadership, adult learning and adult skills and launched the comparative series Education Policy Outlook. She has also worked with individual countries such as Greece, Japan, Mexico, Norway, Sweden and the United Kingdom (Wales) in their school improvement reform efforts.

Previously, Beatriz was a researcher on education and social policies in the Economic and Social Council of the Government of Spain and worked for Andersen Consulting (Accenture). She has also been research fellow at the Institute of Social Sciences (Tokyo University) and at the Laboratory for Interdisciplinary Evaluation of Public Policies (LIEPP, Science Po, Paris).

Beatriz holds a PhD from the Complutense University, Madrid, and an honorary doctorate from Sheffield Hallam University.

Romane Viennet is an analyst at the OECD Directorate for Education and Skills. She worked previously as a social impact analyst in France and as a research assistant in behavioural economics projects at Cornell University, New York. Her research interests include education policy implementation and change processes in public policy.

At the OECD, Romane co-ordinated the implementation assessments of Scotland's Curriculum for Excellence and Wales' Curriculum for Wales. She has also taken part in several tailored country projects on school education policies in Estonia, Ireland, Mexico and Norway, and in the Greek country review.

Romane holds a Master's degree in International Affairs and a Bachelor of Arts in Political Science and Economics, both from Sciences Po, Paris. 


\section{The bottom line: a coherent set of indicators and monitoring principles to support the Estonian Education Strategy 2035}

Estonia is currently finalising its new Education Strategy 2035, a horizon that goes beyond strict education performance and encompasses the knowledge, skills and attitudes for people to thrive in the 21 st century. To achieve the ambitious goals set in the strategy, Estonia requested support from the European Commission, under the Structural Reform Support Programme, in the area of education monitoring and data-informed decision making.

This Policy Perspective presents the final output of this two-year collaboration between the Estonian Ministry of Education and Research, the European Commission, and the OECD. The overall goal of this project is to support the Estonian Government in strengthening data-informed decision making in education through improvements to its education monitoring system. After reviewing comprehensively the existing data and monitoring processes in Estonia, the OECD has prepared guidelines for education monitoring and a coherent set of indicators to support the achievement of the goals set in the Estonian Education Strategy 2035.

The report will be valuable not only for Estonia, but also to the many countries that are looking to strengthen monitoring practices, select relevant indicators, and promote data-informed decision making at every governance level to steer school improvement.

\section{Implementing Policies: supporting change in education}

This document was jointly prepared by the Implementing Education Policies (IEP) and the Indicators of Education Systems (INES) teams at the OECD.

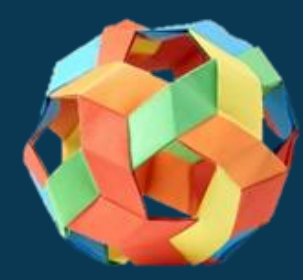

The OECD project Implementing Policies: Supporting Effective Change in Education offers peer-learning and tailored support for countries and jurisdictions to help them achieve success in the implementation of their policies and reforms in school education. The tailored support consists of three complementary strands of work that target countries' and jurisdictions' needs: policy and implementation assessment, strategic advice and implementation seminars.

The Indicators of Education Systems (INES) programme is an authoritative source for internationally comparable information on education around the world. It provides data and indicators on the performance of the education systems in the OECD's 38 member countries and a set of partner countries, including non-member G20 nations.

\section{For more information:}

Contact: Beatriz Pont, project leader, beatriz.pont@oecd.org

Website: OECD Implementing Education Policies 


\section{No. 47 - Enhancing data informed strategic governance in education in Estonia}

The project "Enhancing data-informed strategic governance in education in Estonia" was funded by the European Union via the Structural Reform Work Programme (SRSS/S2019/36). This publication was produced with the financial assistance of the European Union. The views expressed herein can in no way be taken to reflect the official opinion of the European Union.

This work is published under the responsibility of the Secretary-General of the OECD. The opinions expressed and arguments employed herein do not necessarily reflect the official views of OECD member countries.

This document, as well as any data and any map included herein, are without prejudice to the status of or sovereignty over any territory, to the delimitation of international frontiers and boundaries and to the name of any territory, city or area.

The statistical data for Israel are supplied by and are under the responsibility of the relevant Israeli authorities. The use of such data by the OECD is without prejudice to the status of the Golan Heights, East Jerusalem and Israeli settlements in the West Bank under the terms of international law.

The use of this work, whether digital or print, is governed by the Terms and Conditions to be found at http://www.oecd.org/termsandconditions.

Cover Illustration Credit: Christophe Brilhault 